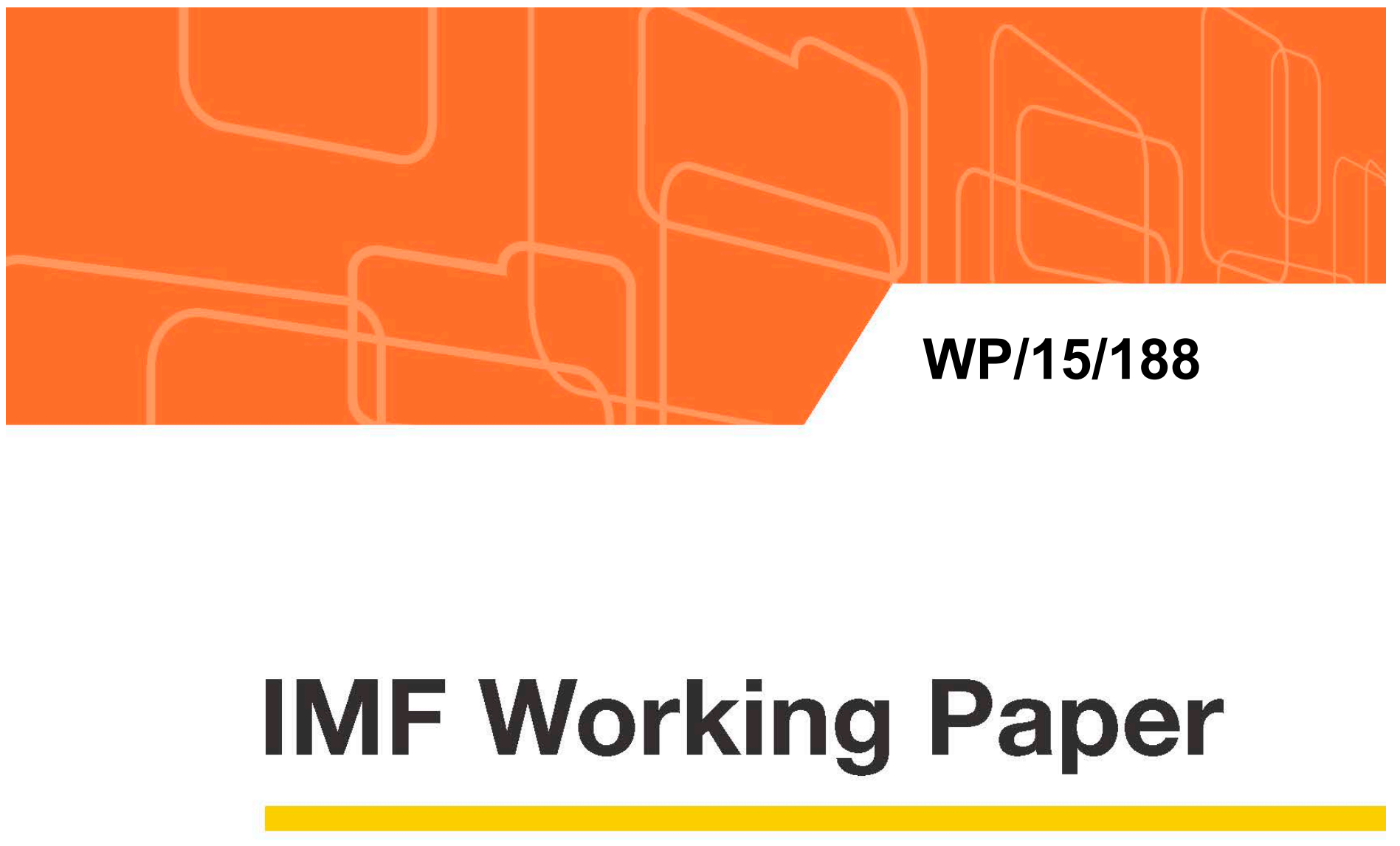

\title{
Trends in Fiscal Transparency: Evidence from a New Database of the Coverage of Fiscal Reporting
}

by Rachel F. Wang, Timothy C. Irwin, and Lewis K. Murara

IMF Working Papers describe research in progress by the author(s) and are published to elicit comments and to encourage debate. The views expressed in IMF Working Papers are those of the author(s) and do not necessarily represent the views of the IMF, its Executive Board, or IMF management.
I $\mathbb{N}$
N T E R
R N A T I O N A L
$M O N E T A R Y$
$F \cup \mathbb{N}$ 


\title{
IMF Working Paper
}

Fiscal Affairs Department

\section{Trends in Fiscal Transparency: \\ Evidence from a New Database of the Coverage of Fiscal Reporting}

\author{
Prepared by Rachel F. Wang, Timothy C. Irwin, and Lewis K. Murara \\ Authorized for distribution by Richard Hughes
}

August 2015

\section{IMF Working Papers describe research in progress by the author(s) and are published to} elicit comments and to encourage debate. The views expressed in IMF Working Papers are those of the author(s) and do not necessarily represent the views of the IMF, its Executive Board, or IMF management.

\begin{abstract}
Although there are several measures of fiscal transparency, none provides satisfactory information on certain issues of macroeconomic relevance, including whether fiscal data are available for all of general government, whether the government reports a balance sheet, and whether spending and revenue are reported on a cash or accrual basis. Drawing on government finance statistics reported to the IMF, this paper presents a new database of fiscal transparency for 186 countries in 2003-13 and derives from it indices of the overall comprehensiveness of fiscal statistics as well as specific indices of the coverage of public institutions, fiscal flows, and fiscal stocks, respectively. It finds evidence of gradual improvement, most notably in the coverage of institutions, but most countries' reporting remains far from comprehensive.
\end{abstract}

JEL Classification Numbers: H60, H83, E01

Keywords: public finance, budgets, accounts, fiscal transparency, fiscal reporting, government finance statistics

Authors’ E-Mail Address: rachel.f.wang@gmail.com, tirwin@imf.org, and lmurara@imf.org 


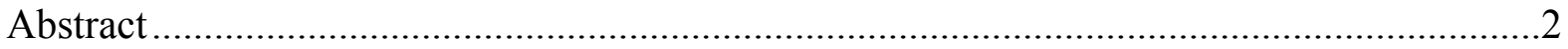

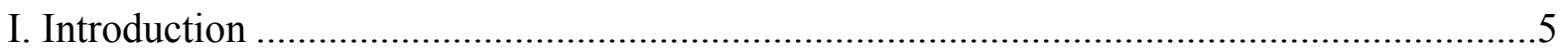

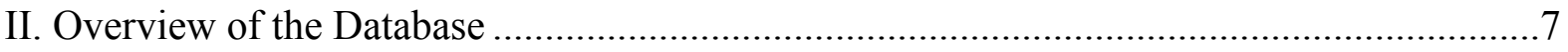

III. Correlations with other Indices of Transparency and Governance................................13

IV. Trends in 2003-13 and Variation among Country Groups .........................................17

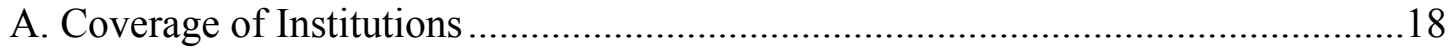

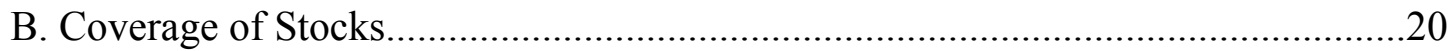

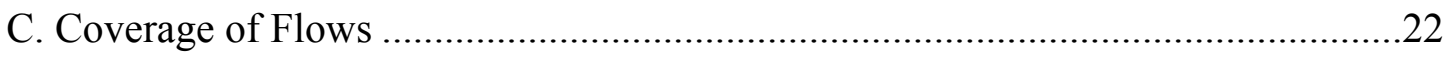

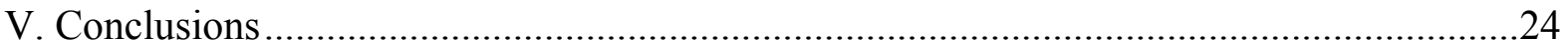

\section{TABLES}

1. Descriptive Statistics for GFS Indicators, 2013 .................................................... 13

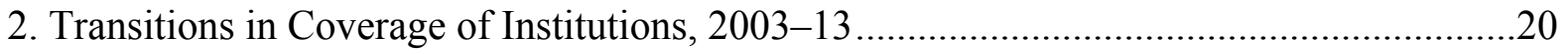

3. Transitions in Coverage of Stocks, 2003-13 …...........................................................22

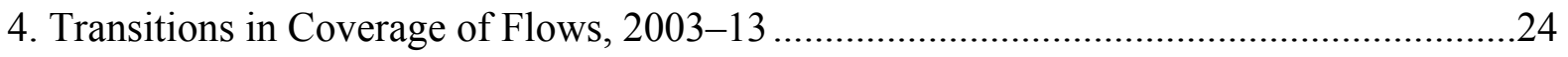

\section{FIGURES}

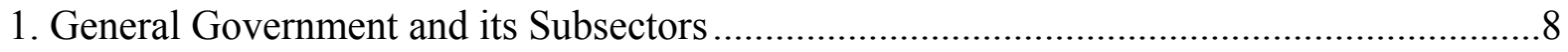

2. Average Comprehensiveness of GFS, 2011-13: Top Quartile....................................... 10

3. Relationships among Measures of Comprehensiveness of GFS ..................................... 14

4. Relationships among Measures of Fiscal Transparency ................................................15

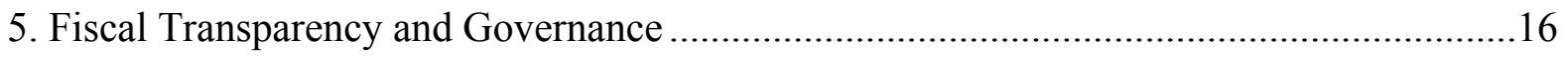

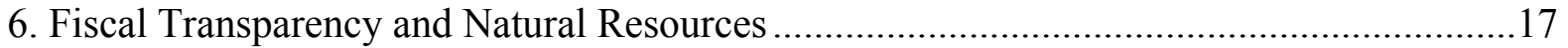

7. Average Comprehensiveness of GFS, 2003-13 …........................................................... 18

8. Average Comprehensiveness of the Coverage of Institutions, 2003-13 ..........................19

9. Average Comprehensiveness of the Coverage of Stocks, 2003-13 ................................21

10. Average Comprehensiveness of the Coverage of Flows, 2003-13 ................................23

\section{APPENDIXES}

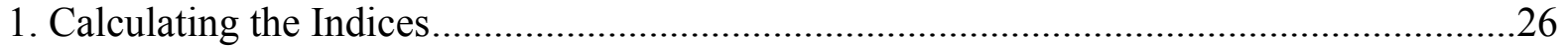

2. Deriving an Indicator of Fiscal Transparency from PEFA Reports .................................33 


\section{APPENDiX TABLES}

A1. Summary Statements for Austria, 2012 Yearbook

A2. Basic Data for Austria, 2012 Yearbook

A3. Coverage of Stocks, Austria, 2012 Yearbook

A4. Coverage of Flows in Austria, 2012 Yearbook

A5. Coverage of Institutions in Austria, 2012 Yearbook

A6. Descriptive Statistics for PEFA Indicators

APPENDIX Figure

A1. Top PEFA Scorers 


\section{INTRODUCTION ${ }^{1}$}

The last two decades have seen a resurgence of interest in fiscal transparency (IMF, 2012). Many governments now publish not only their budgets and accounts but many other documents on public finances, such as prebudget statements, medium-term forecasts, and statistics that consolidate the finances of national and subnational governments. The IMF has developed norms for fiscal transparency generally and for the reporting of fiscal statistics specifically, the most recent being the Fiscal Transparency Code of 2014 and the Government Finance Statistics Manual 2014. Other organizations have also issued guidelines on the publication of fiscal information, including the Organisation for Economic Cooperation and Development (OECD, 2002), the European Union (e.g., Eurostat, 2013), and the International Public Sector Accounting Standards Board (IPSASB, 2014).

Several indices of fiscal transparency have been developed, including by Alt and Lassen (2006), Bernoth and Wolff (2006), and Jarmuzek and others (2006). ${ }^{2}$ At the IMF, Hameed (2005) derived an index of transparency from reports that evaluated 56 countries' compliance with the first versions of the IMF's Code. (Hameed's work has subsequently been updated.) Dabla-Norris and others (2010) developed indicators of fiscal transparency (among other things) in low-income countries. Weber (2012) merged these two sources of data to generate an index for a larger set of countries. Notably, the International Budget Partnership has published the Open Budget Index every two years since 2006 (IBP, 2012). ${ }^{3}$

${ }^{1}$ For comments and other help, the authors would like to thank Jim Alt, Miguel Alves, Oleksii Balabushko, Marco Cangiano, Valerio Crispolti, Lewis Hawke, Richard Hughes, Barbara Liu, Brandon Lundberg, Xavier Rame, Carla Sateriale, Joachim Wehner, and participants in a seminar held by the Fiscal Affairs Department. They would especially like to thank the Government Finances division of the IMF's Statistics Department, including Sagé De Clerck, Gary Jones, Alberto Jimenez de Lucio, Viera Karolova, Mike Seiferling, Philip Stokoe, and Murto Wickens.

${ }^{2}$ Also worth noting is the work of Koen and van den Noord (2005, Table A1), who, though they do not aim to construct an index of fiscal transparency, estimate the extent of "fiscal gimmickry" and other measures that cause fiscal accounts to present a misleading picture of public finances in 15 European countries in the period 1993-2003.

${ }^{3}$ These indices have been used in research on fiscal transparency by, among others, Alt and Lassen, 2006; Alt, Lassen, and Rose, 2006; Khagram, Fung, and de Renzio, 2013; Seiferling 2012; Seiferling and Tareq, 2014; and Weber, 2012. For a review of the evidence on the effect of "fiscal openness," see de Renzio and Wehner (2015), who conclude that the most rigorous tests tend to find that it is beneficial. 
Though valuable, the existing measures of transparency leave important gaps:

- $\quad$ Some cover only small samples of high-incomes countries (Alt and Lassen, 2005; Bernoth and Wolff, 2006) or countries from a particular region (Jarmuzek and others, 2006).

- $\quad$ Most are available for only a single time period. Fiscal transparency typically changes gradually, so for some purposes the lack of a time series is not a major drawback, but transparency does change, sometimes rapidly (IBP, 2012).

- The Open Budget Index has the advantage of covering both a large sample of countries - 100 in 2012 - and of being periodically repeated. Despite its value, however, the Index does not provide much information on the comprehensiveness of fiscal aggregates. For example, it does not report whether a country publishes an estimate of the fiscal deficit for all of general government or only for central government or whether the deficit is estimated on a cash basis, an accrual basis, or both. ${ }^{4}$

These gaps are important for macroeconomic monitoring. For example, if no information is published on the deficit of general government, it may be difficult to tell whether a reduction in the reported deficit reflects a change in fiscal policy or a shifting of spending responsibilities between central and local government. Likewise, if no information is published on government assets, and the deficit is recorded on only a cash basis, the government's accounts may not reveal whether a reduction in the deficit is enduring or whether it depends on a one-off boost from asset sales.

Building on IMF (2012) and Blondy and others (2013), this paper presents a new database of indicators of one aspect of fiscal transparency - that is transparency about certain fiscal aggregates especially relevant for macroeconomic monitoring. The database is drawn from information reported to the IMF's Statistics Department by IMF member countries for publication in Government Finance Statistics (GFS) Yearbooks. These yearbooks have been published for several decades, but we begin with the 2003 Yearbook, which was the first to present data in the form prescribed by the Government Finance Statistics Manual 2001 (IMF, 2001). Unlike the earlier edition (IMF, 1986), the 2001 Manual provided for balance sheets and both cash and accrual data on revenue, spending, and financing. The database describes:

\footnotetext{
${ }^{4}$ This is not to say that the Open Budget Survey provides no information relevant to these issues. It does include questions on whether the budget and related reports contain information on extrabudgetary funds, quasifiscal activities, budgetary transfers to subnational governments and public corporations, and the government's assets (IBP, 2011, including questions 35, 38, 39, 40, 86, 91).
} 
- $\quad$ whether a country has reported fiscal data for general government, central government, or budgetary central government

- $\quad$ whether it has reported data on revenues and spending on a cash basis, an accrual basis, or both

- whether it has reported a full balance sheet, a financial balance sheet, or only liabilities.

From the database, we derive indices of the comprehensiveness of the statistical coverage of institutions, fiscal stocks, and fiscal flows, respectively, as well as an overall measure of the comprehensiveness of government finance statistics.

Comprehensiveness is, of course, only one of the desirable features of fiscal data. Reliability and timeliness, for example, also matter. Unfortunately, these features are not amenable to measurement using our sources. In addition, the measures are derived solely from information submitted to the IMF and therefore ignore other publicly available information. Finally, they consider only aggregate data and not, for example, whether there are detailed breakdowns of government spending and revenue into component categories.

Nevertheless, the new indicators have three important advantages. They provide previously unavailable information on the comprehensiveness of a key source of fiscal data. They cover 186 countries. And they form an annual time series going back to 2003.

The rest of the paper is organized as follows. Section II describes the database, explains how the indicators of fiscal transparency are constructed, and presents some basic results. Section III shows that the new indicators are correlated with each other and that the overall indicator of the comprehensiveness of government finance statistics is correlated with other measures of fiscal transparency, including the Open Budget Index, Weber's (2012) index, and an indicator derived from Public Expenditure and Financial Accountability reports. Section IV reports changes in the indicators over time and variations among country groups, revealing gradual increases in the comprehensiveness of government finance statistics, but also some backward steps.

\section{OVERVIEW OF THE DATABase}

Government Finance Statistics Yearbooks provide for data on the finances of six possible sets of institutions, some of them subsets of others (Figure 1). Among these are three increasingly encompassing definitions of government: budgetary central government, central 
government (which also includes extrabudgetary funds), and general government (which also includes state and local government). ${ }^{5}$

Figure 1. General Government and its Subsectors

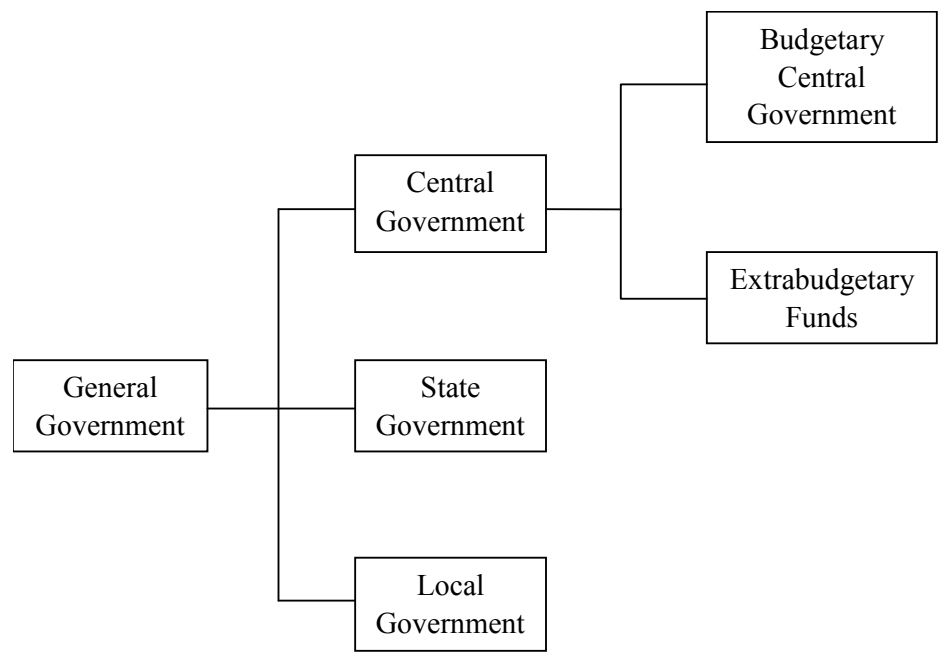

Source: IMF (2001) and authors.

Note: Social security is sometimes treated as a subsector of its own. Here it is treated as part of central or local government.

For each of these sectors, government finance statistics can provide information on various fiscal flows and stocks, including:

- $\quad$ Revenue, spending, and financing measured on a cash basis, shown in a statement of the sources and uses of cash;

- $\quad$ Revenue, spending, and financing measured on an accrual basis, shown in a statement of government operations;

- $\quad$ Fiscal stocks, shown in a balance sheet that can include liabilities, financial assets (e.g., bonds and accounts receivable), and nonfinancial assets (e.g., land and buildings); and

- $\quad$ Changes in the values of assets and liabilities not associated with revenue or spending (e.g., capital gains), shown in a statement of other economic flows.

For most countries, the data are far from complete. Some countries report data for general government, but some report only for central government or budgetary central government.

${ }^{5}$ Broader than general government is the public sector, which includes the financial and nonfinancial corporations controlled by general government, but the broadest coverage included in the Yearbooks is general government. 
Some countries report a full balance sheet. Others report only a financial balance sheet (one that excludes nonfinancial assets). Still others report only liabilities. And a last group reports no information at all on fiscal stocks. Similarly, some countries report only a statement of the sources and uses of cash. Others produce only an accrual-based statement of government operations. ${ }^{6}$ Some produce both, and a small group also produces the statement of other economic flows.

The database presented here shows, for each country in each year, which information has been reported for which subsectors of general government. More specifically, it shows, for each of the six possible subsectors of general government (including general government itself), which of the following six pieces of information have been reported: (i) liabilities, (ii) financial assets, (iii) nonfinancial assets, (iv) the statement of the sources and use of cash; (v) the statement of government operations; and (vi) the statement of other economic flows.

Our approach to measuring the comprehensiveness of government finance statistics-others can use the data differently - is essentially to assume that more is better. When considering the breadth of institutional coverage, we note that some countries have no state or local government or no extrabudgetary funds and, for the purpose of the constructing the index, we therefore ignore these subsectors. ${ }^{7}$ This leaves budgetary central government, central government, and general government. In relation to these three increasingly broad sets, we assume that broader coverage is always better. Then, for each of the six items listed above, we give the country a score according to the breadth of the institutional coverage for that item:

- $\quad 0$ if it does not report the item

- 1 if it reports the item for budgetary central government, but not central or general government

- 2 if it reports the item for central government, but not general government

- 3 if it reports the item for general government.

That gives a maximum raw score of 18 , which a country receives it reports all six items for general government. We convert the raw score to a score out of 100. (Appendix 1 explains in more detail how the index is constructed, and discusses some alternative constructions.)

\footnotetext{
${ }^{6}$ Although the statement of government operations is in principle accrual-based, countries may report it even if the data are not fully on an accrual basis.

${ }^{7}$ In principle, one might count these sectors if and only if they were applicable in the country. We have not done this. Note also that, for reasons of space, the Yearbooks only allow for four different sets of institutions.
} 
Figure 2 reports the top quartile of countries according the index, over the three-year period 2011-13. The database itself provides a full listing of countries for each of the years 2003 to 2013.

Figure 2. Average Comprehensiveness of GFS, 2011-13: Top Quartile

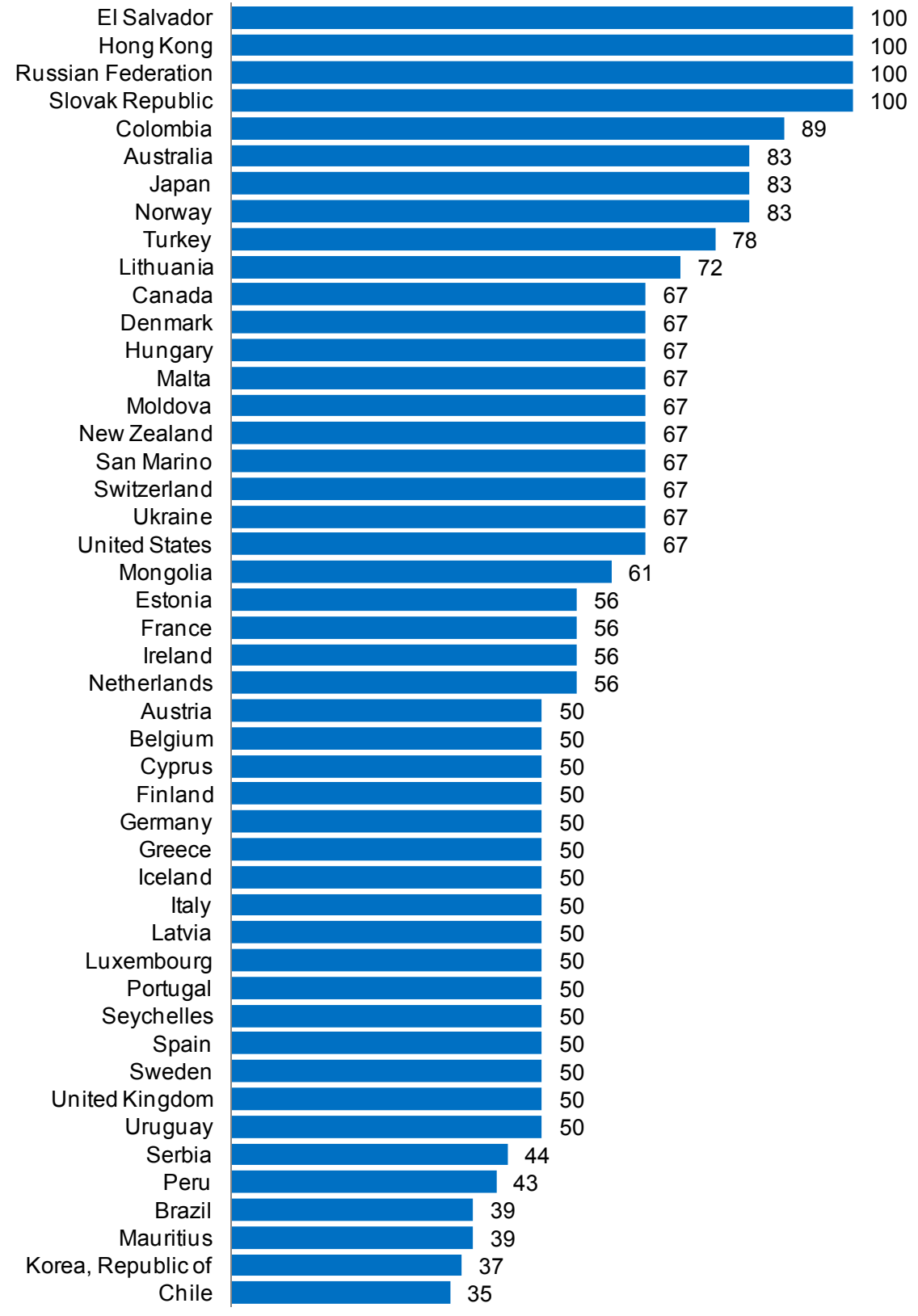

Some of the information revealed by Figure 2 is not surprising: the countries in the top quartile include most of those classified by the IMF as advanced. But the top four countries - El Salvador, Hong Kong SAR, Russia, and the Slovak Republic — may be surprising. As noted above, the index measures just one aspect of fiscal transparency, namely 
the comprehensiveness of aggregate government finance statistics. By comparison, in the 2012 Open Budget Index, Russia and the Slovak Republic get fairly high scores, but they are not at the very top of the ranking (they are 10th and 15th out of 100, respectively) while El Salvador has a relatively low ranking. (For an analysis of fiscal transparency in Russia, see also Hughes and others, 2014.)

Using the indicators, we also create indices for each of the three dimensions of the comprehensiveness of fiscal data-institutions, stocks, and flows. To measure the comprehensiveness of the coverage of public institutions, we ignore the comprehensiveness of the reporting of fiscal flows and stocks. Similarly, to measure the comprehensiveness of the coverage of stocks and flows, we ignore the comprehensiveness of the coverage of public institutions. More specifically:

- For institutions, we assign a score of 3 if the country reports either a statement of government operations or a statement of the sources and uses of cash for general government. A score of 2 means it reports either of these statements for central government, but not for general government, and a score of 1 means it reports either of these statements for budgetary central government, but not for central government or general government. These scores reflect the path that countries most often follow in improving statistics: data on general government are not usually produced before data on central government, which in turn are seldom produced before data on budgetary central government.

- $\quad$ For stocks, we just count balance-sheet subtotals. So, a score of 3, for example, means the country reports liabilities, financial assets, and nonfinancial assets, for any of the three main definitions of government-budgetary central government, central government, or general government. Although the scores simply count items, a 1 almost always means that the country reports liabilities, while a 2 almost always means it reports a financial balance sheet.

- $\quad$ For flows, we count statements. For example, we assign a score of 3 if the country reports all three flow statements (cash, government operations, and other economic flows) for any of the three main definitions of government - budgetary central government, central government, or general government. Most countries reporting a single flow statement report the statement of sources and uses of cash, but several countries (in the European Union, in particular) report only a statement of government operations. Countries that report exactly two statements might report the statement of sources and use of cash and the statement of government operations or they might report the statement of government operations and the statement of other economic flows.

These three specific indicators are closely related to the first three principles of the IMF's Fiscal Transparency Code (IMF, 2014). 
- $\quad$ The first principle of the Code relates to the comprehensiveness of the coverage of public institutions. "Advanced practice," according to the Code, is to publish data for the entire public sector. Government Finance Statistics Yearbooks have not provided for the reporting of data on the public sector, so it is not possible to use data from this source to test adherence to advanced practice. "Good practice," however, is to prepare data on general government, and "basic practice" is to prepare data on central government. Thus the indicator of the coverage of the public institutions shows whether a country complies with good practice, whether it complies with basic practice, or whether it does not even meet the standard of basic practice.

- $\quad$ The second principle in the Code relates to the comprehensiveness of the coverage of fiscal stocks. Advanced practice is to publish a full balance sheet, good practice is to publish a financial balance sheet, and basic practice is to report cash and debt. The index presented here is consistent with this norm, except that the lowest positive score is assigned to countries that report a figure for "liabilities" rather than for countries that report debt and cash. This reflects the structure of the data in the Yearbooks, which include summary balance sheets with three subtotals: liabilities, financial assets, and nonfinancial assets.

- $\quad$ The third principle relates to the comprehensiveness of the coverage of fiscal flows. Basic practice is to report cash flows, good practice is to report cash and accrual flows, and advanced practice requires the reporting of other economic flows as well. The index takes a similar approach, though it simply counts statements rather than ordering them.

Table 1 shows descriptive statistics for these three indicators, as well as for the overall index. It reveals that the performance of the median country is still rather poor. The median values represent reporting a single flow statement (typically a cash-flow statement but sometimes a statement of government operations) for budgetary central government. They imply the reporting of no balance sheet at all. Overall, the median country scores only 11 out of a possible 100. One reason that the median scores are low, and mostly lower than the means, is that 36 countries reported no government finance statistics at all for the 2013 Yearbook. There are, however, large variations among regional and among income groups; these are discussed in Section IV. 
Table 1. Descriptive Statistics for GFS Indicators, 2013

\begin{tabular}{|c|c|c|c|c|}
\hline & Mean & Median & Maximum & Minimum \\
\hline $\begin{array}{l}\text { GFS Index Score } \\
\text { (Out of } 100)\end{array}$ & 23.5 & 11.1 & 100.0 & 0.0 \\
\hline $\begin{array}{l}\text { Coverage of Institutions } \\
\text { (Out of } 3 \text { ) }\end{array}$ & 1.7 & 1.0 & 3.0 & 0.0 \\
\hline $\begin{array}{l}\text { Coverage of Stocks } \\
\text { (Out of } 3 \text { ) }\end{array}$ & 0.8 & 0.0 & 3.0 & 0.0 \\
\hline $\begin{array}{l}\text { Coverage of Flows } \\
\text { (Out of } 3 \text { ) }\end{array}$ & 0.8 & 0.9 & 3.0 & 0.0 \\
\hline
\end{tabular}

Source: Government Finance Statistics Yearbooks 2013.

\section{CORRELATIONS WITH OTHER INDICES OF TRANSPARENCY AND GOVERNANCE}

The four GFS-based indicators of fiscal transparency are positively correlated with each other (see Figure 3, in which the overall index is labeled "GFS score"). First, countries that are good at reporting fiscal stocks are generally good at reporting fiscal flows (see the scatter plot in the third column); the correlation coefficient is 0.73 . This relationship is not surprising since accrual measures of fiscal flows are defined in terms of fiscal stocks. Second, the coverage of stocks and the coverage of flows are also positively correlated with the coverage of institutions (second column); the correlation coefficients are 0.68 and 0.79 , respectively. Here, there is no strong conceptual link: it is possible to produce data on revenue and spending with a broad institutional coverage, while reporting no assets or liabilities and only one flow statement. As a matter of practice, however, improvements in institutional coverage usually tend to go along with improvements in the coverage of stocks and flows- though, as the upper scatter plot in the second column shows, there are plenty of countries with good coverage of institutions but poor coverage of fiscal stocks. Third, the overall GFS score is closely correlated with the component indices (first column); the correlation coefficients are 0.79 (institutions), 0.94 (stocks), and 0.86 (flows). 
Figure 3. Relationships among Measures of Comprehensiveness of GFS

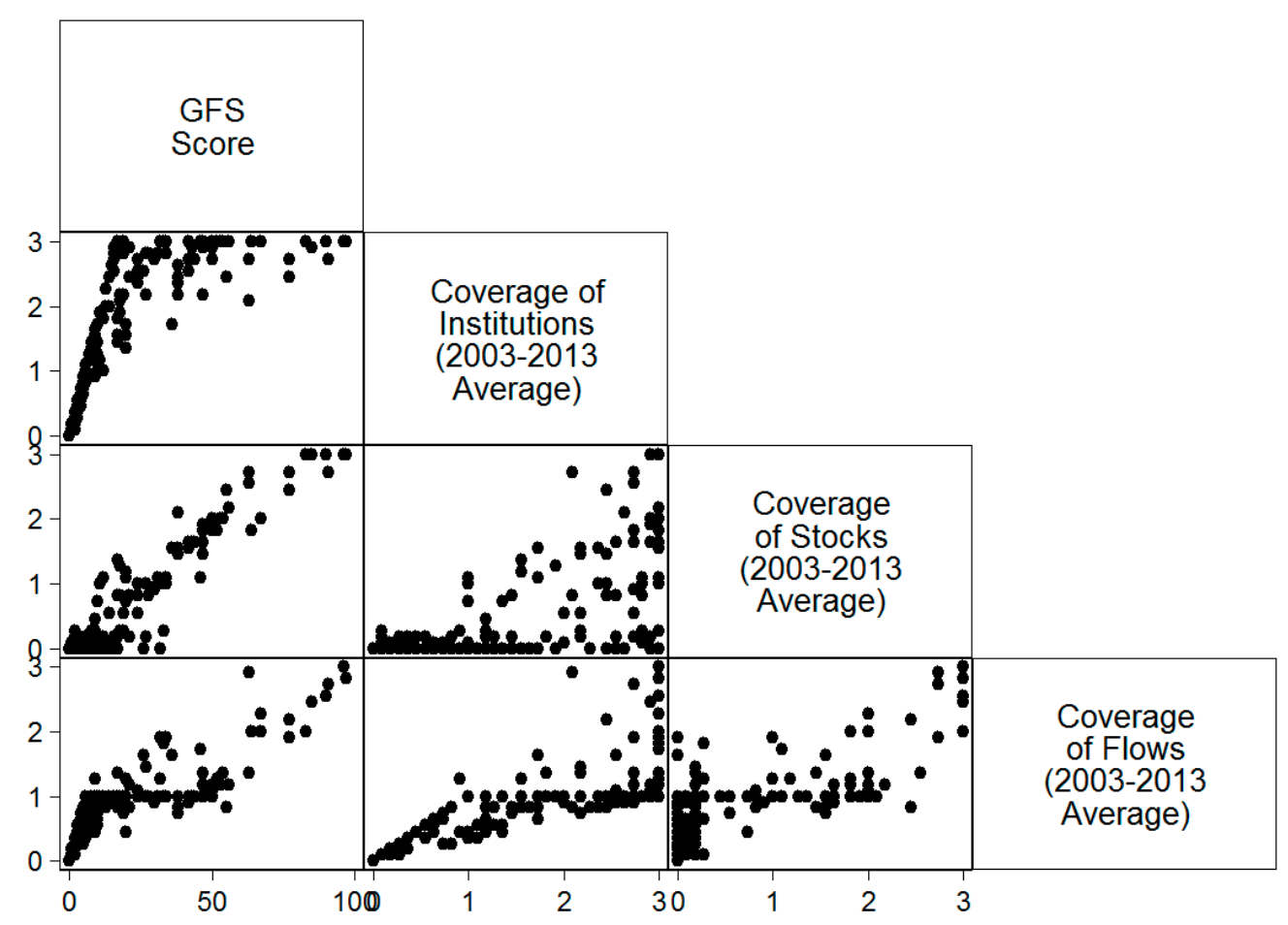

Source: Government Finance Statistics Yearbooks 2003-13 and authors.

The overall index of the comprehensiveness of government finance statistics is also positively correlated with other measures of fiscal transparency (Figure 4, first column). The correlation between the index (for 2003-13) and the Open Budget Index 2012 is 0.60, ${ }^{8}$ while the correlation between the index and Weber's (2012) index is 0.62. The index is also positively correlated with a measure of fiscal transparency that can be derived from reports on Public Expenditure and Financial Accountability reports (see Appendix 2 for details). Though not shown in the scatter plots, the GFS-based index also tends to be higher in countries that have older freedom-of-information laws - another indicator of openness: the 93 countries with no freedom-of-information law have an average GFS score of 9.3, while the six countries whose law is more than 30 years old have an average GFS score of $60.3 .^{9}$

\footnotetext{
${ }^{8}$ Although the OBI score is for 2012, the average GFS score for the period 2003-13. One might expect a tighter relationship between the OBI of 2012 and the GFS score for the 2013 Yearbook, but the correlation coefficients is in fact slightly lower (0.58).

${ }^{9}$ Derived from data on the website of the Center for Law and Democracy.
} 
Figure 4. Relationships among Measures of Fiscal Transparency

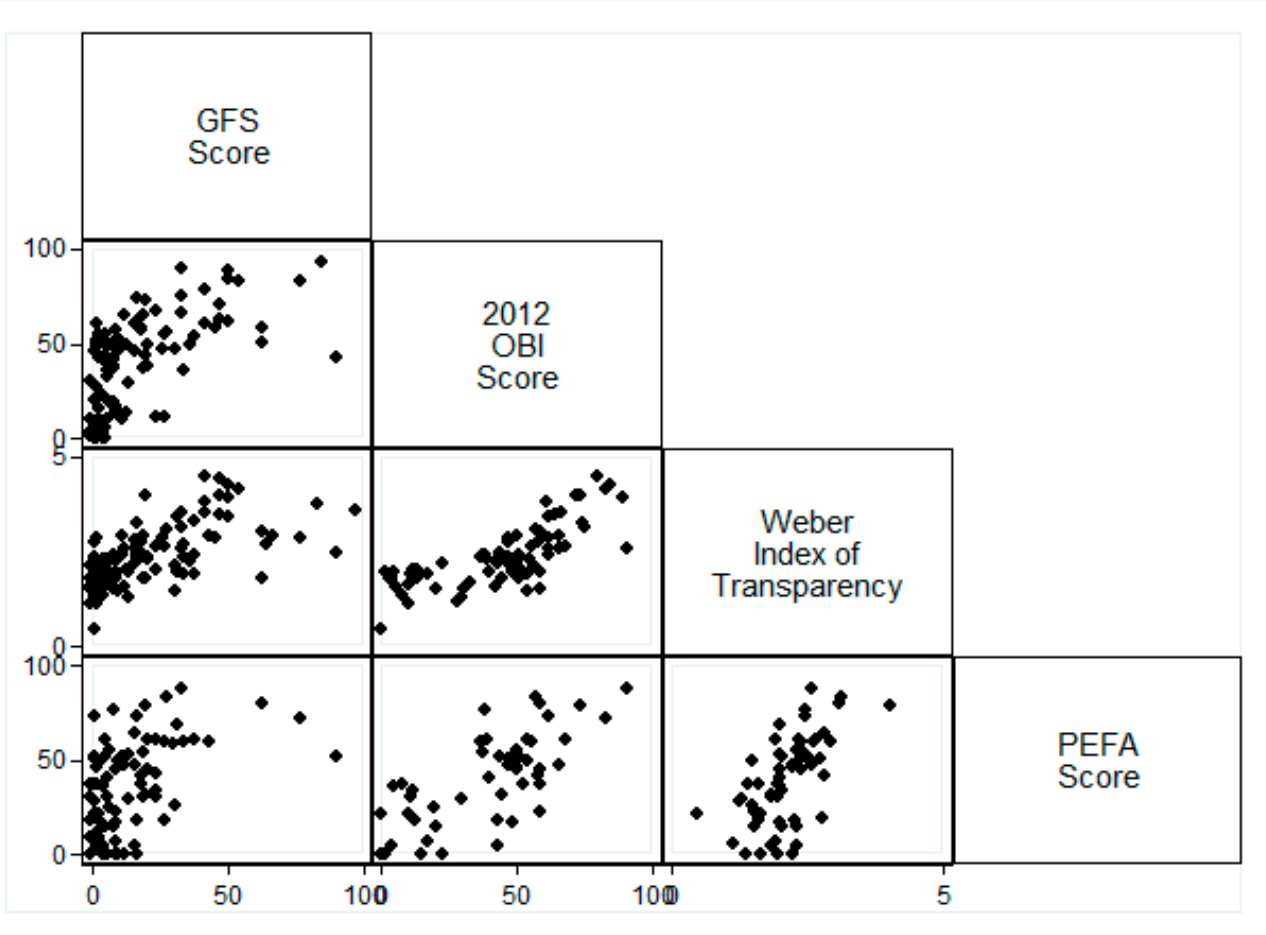

Source: Government Finance Statistics Yearbooks 2003-13, PEFA Reports 2005-2014, IBP (2012), and Weber (2012).

Note: The GFS score is an average for 2003-13. The PEFA score for countries with more than one PEFA report is an average.

The GFS-based index is also positively correlated with indicators of governance (Figure 5). It is loosely but positively correlated with the World Bank's index of voice and accountability (one of the Worldwide Governance Indicators) and loosely but negatively correlated with the Economist Intelligence Unit's ranking of countries from the most to the least democratic. In general, former Eastern-bloc countries tend to have more comprehensive statistics than would be expected given their governance and incomes. 
Figure 5. Fiscal Transparency and Governance

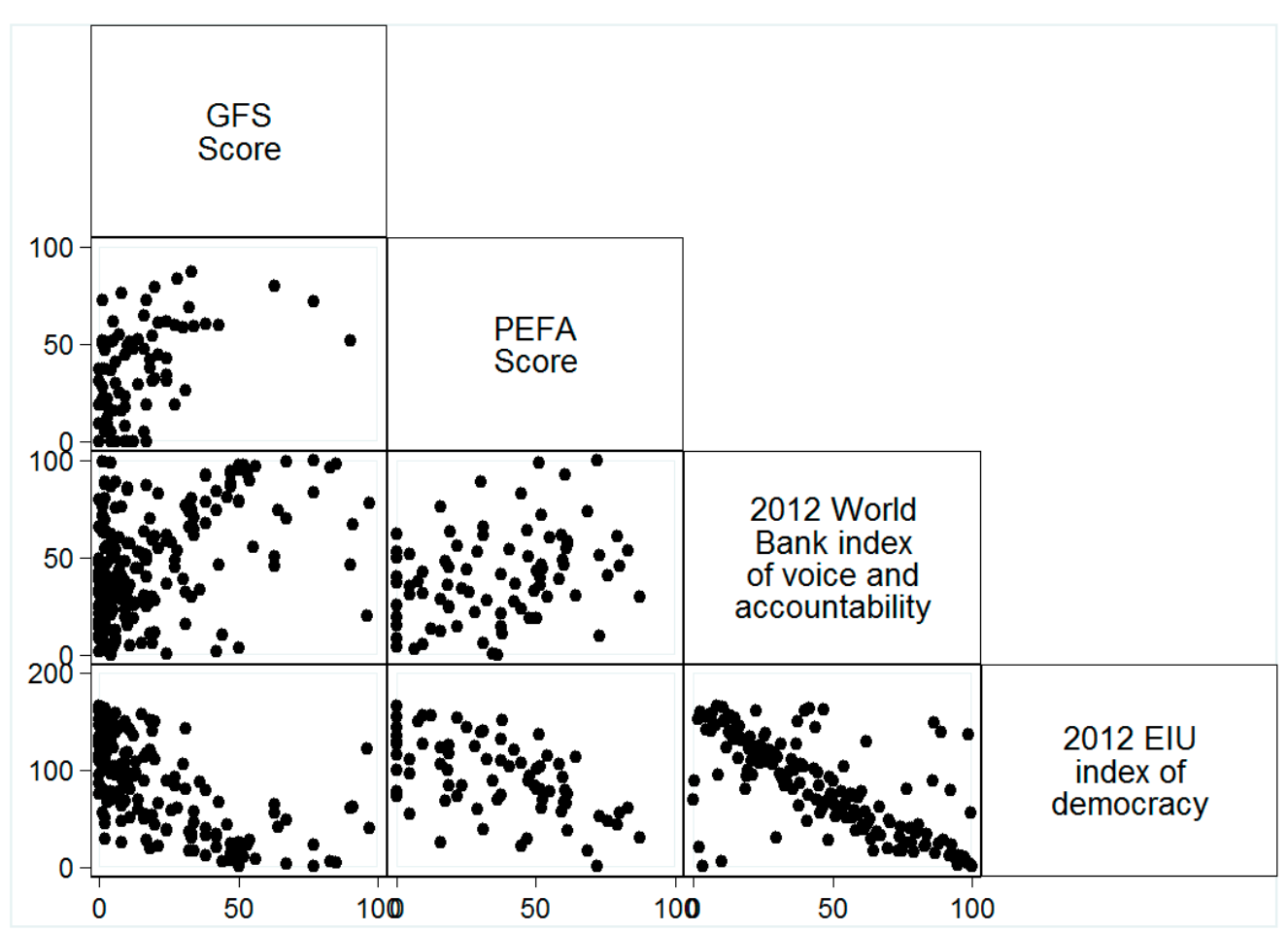

Source: Government Finance Statistics Yearbooks 2003-13, PEFA Reports 2005-14, World Bank Worldwide Governance Indicators 2012, and Economist Intelligence Unit (2012).

Another factor that may influence transparency is the source of the government's revenue. Figure 6 shows that the GFS-based index of fiscal transparency is loosely negatively correlated with a measure of resource-revenue dependence (the correlation coefficient is 0.36). This is consistent with the idea that reliance on taxes, as opposed to resource revenues, makes governments more responsive to citizens and thus more fiscally open. Once the relationship between resource-dependence and per-capita income is controlled for, the relationship becomes somewhat stronger. For similar reasons, it might be thought that countries with strong legislatures would have more comprehensive fiscal statistics, since historically legislatures have often demanded fiscal information in response to requests to levy more taxes (Irwin, 2013). But there is no clear relationship between the GFS score and Wehner's (2006) measure of legislative power. 
Figure 6. Fiscal Transparency and Natural Resources

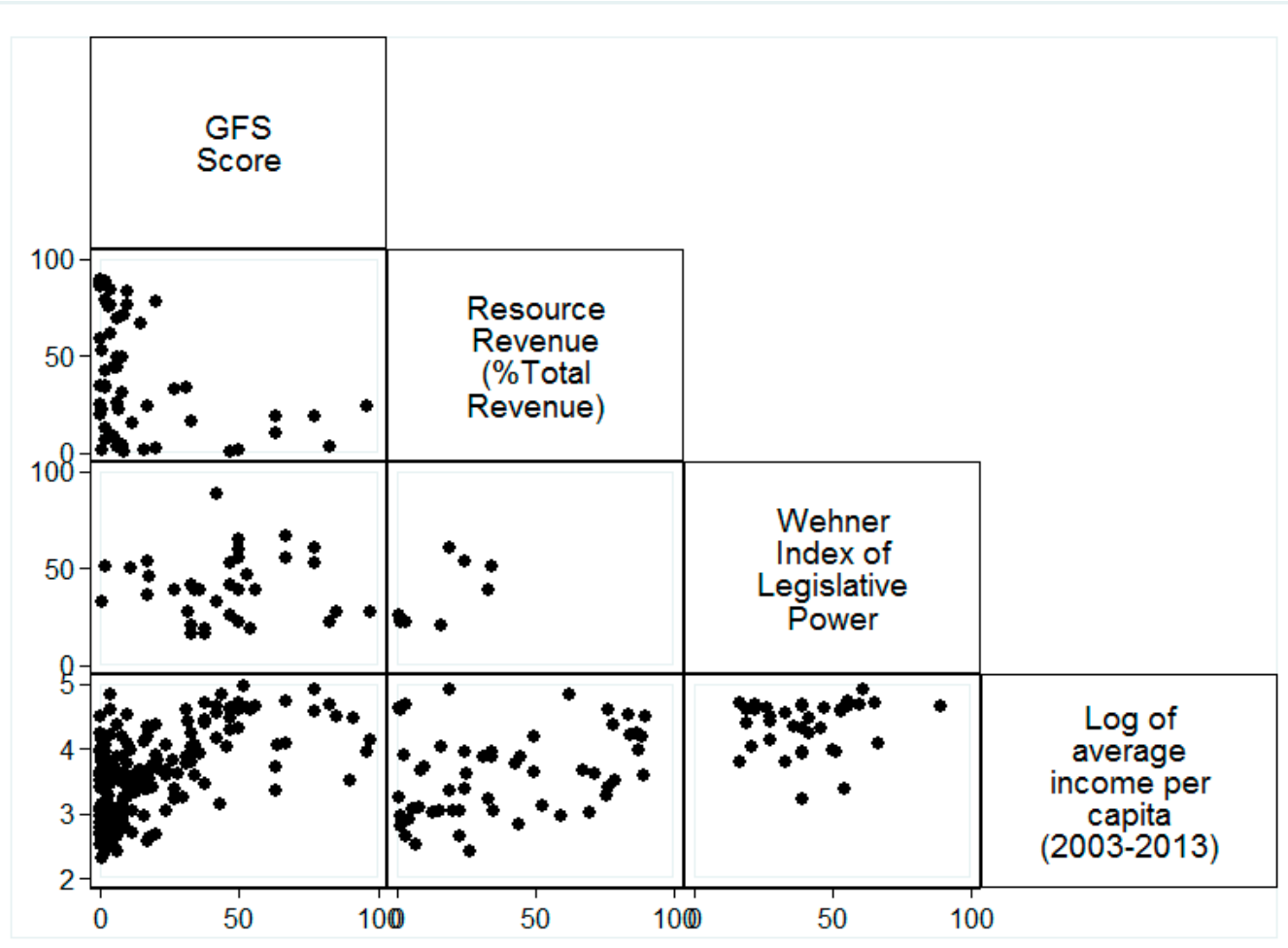

Source: Government Finance Statistics Yearbooks 2003-13, PEFA Reports 2005-2014, IBP (2012), Wehner (2006), and (for resource revenue) IMF Staff estimates.

\section{TRENDS IN 2003-13 AND VARIATION AMONG COUNTRY GROUPS}

Overall, the comprehensiveness of government finance statistics has increased over the past decade. In 2003, the mean score on our overall index was 15.2 out of 100; by 2013, it was 23.5. The improvements have occurred in all regions (Figure 7(a)), but Europe stands out as having the most comprehensive statistics of any region, partly no doubt because of its high average income, but probably also because of the influence of the European Union's fiscal rules, compliance with which is tested using data very similar to the government finance statistics reported to the IMF. As a result, Eurostat and national statistical agencies have devoted considerable resources to producing and improving fiscal data. Figure 7(b) shows that, on average, advanced economies do better than emerging markets, which in turn do better than low-income countries. In all income groups, however, the comprehensiveness of government finance statistics has increased, though in low-income countries the improvement is slight. The overall improvements reflect improvements in the comprehensiveness of each of the three specific aspects of coverage: institutions, stocks, and flows. 
Figure 7. Average Comprehensiveness of GFS, 2003-13

(a) By Region

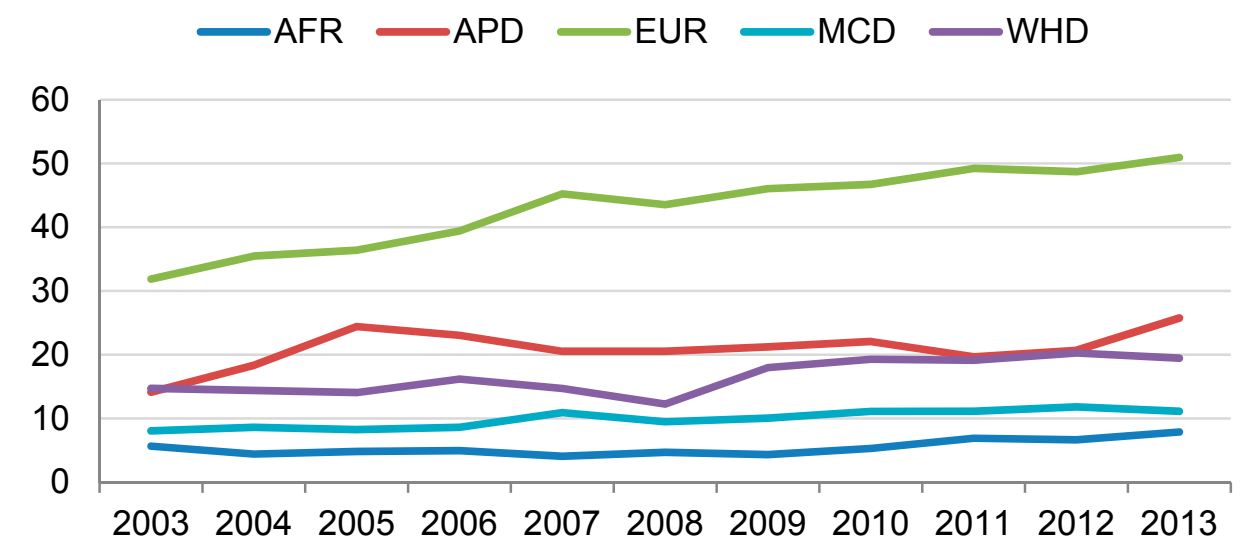

(b) By Income Group

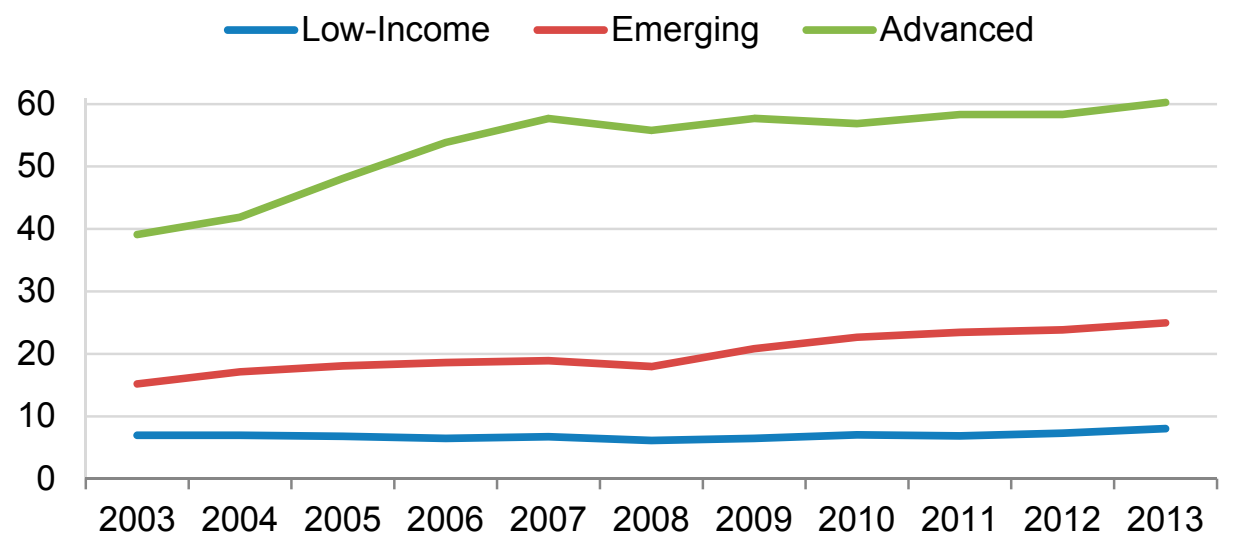

Source: Government Finance Statistics Yearbooks 2003-13.

Note: Year is the year of reporting, not of the data. See Appendix for details.

\section{A. Coverage of Institutions}

First, the institutional coverage of reporting has generally improved. In 2003, the mean score on this dimension was 1.25 out of 3; by 2013, it was 1.71. By now, most European countries and all advanced countries report data for general government (Figures 8(a) and (b), respectively). The net improvement, however, occurred despite backward steps in some countries.

Table 2 examines the changes between endpoints of the period under consideration, the 2003 and 2013 Yearbooks. Panel (a) shows that in 83 countries the comprehensiveness of the coverage of institutions improved, while in 22 it got worse, and in 81 it stayed the same. 
Panel (b) shows the precise nature of the transitions. Cells in red indicate deteriorations. Cells in green indicate improvements. Cells in yellow indicate no change. The rows sum to give totals for the 2003 Yearbook, while the columns sum to give total for the 2013 Yearbook. The biggest improvements come from countries that did not report anything for the 2003 Yearbook. As the top row shows, 39 of these countries reported data for budgetary central government in the 2013 Yearbook, 4 reported data for central government, and 15 reported data for general government. But there were also net improvements in countries that in 2003 reported data for budgetary central government and in countries that reported data for central government. There were also backward steps: for example, 2 countries that reported data for general government in 2003 reported data only for budgetary central government in 2013 and 2 dropped out of the Yearbook altogether.

Figure 8. Average Comprehensiveness of the Coverage of Institutions, 2003-13

(a) By Region

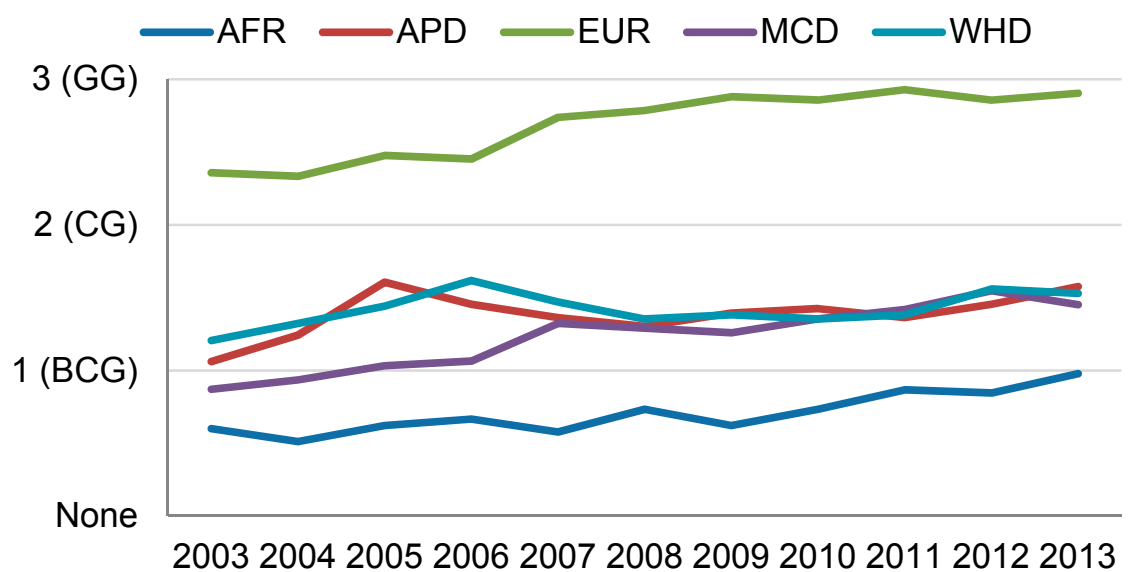

(b) By Income Group

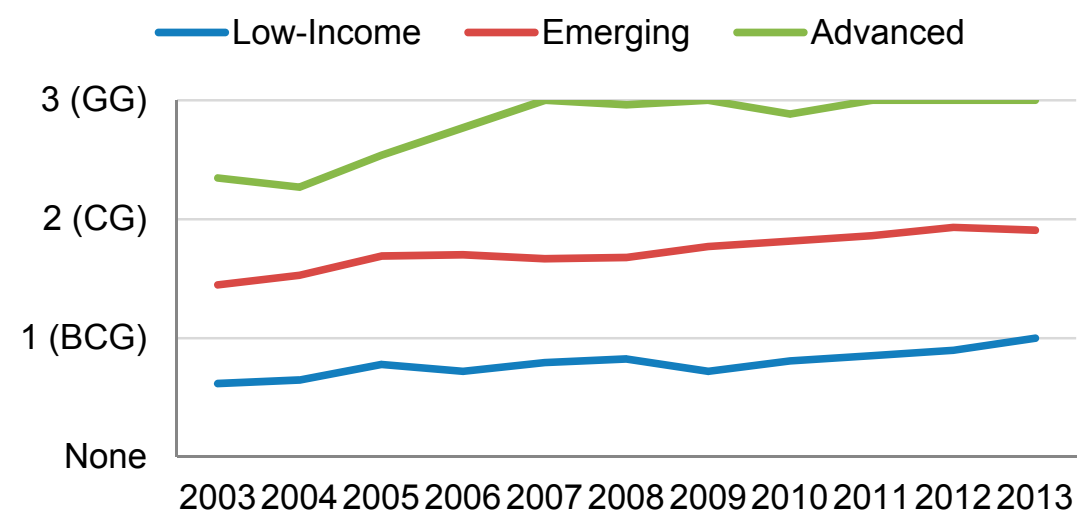

Source: Government Finance Statistics Yearbooks 2003-13.

Note: GG is general government. CG is central government. BCG is budgetary central government. See Note to Figure 3. 
Table 2. Transitions in Coverage of Institutions, 2003-13

(a) Summary

\begin{tabular}{|c|c|c|}
\hline Color & Change & Number of Countries \\
\hline & Improved & 83 \\
\hline & Declined & 22 \\
\hline & No change & 81 \\
\hline
\end{tabular}

(b) Matrix

2013 GFS Yearbook

\begin{tabular}{|c|c|c|c|c|}
\hline & No Coverage & BCG & CG & GG \\
\hline No Coverage & 23 & 39 & 4 & 15 \\
\hline BCG & 3 & 14 & 0 & 5 \\
\hline CG & 8 & 7 & 4 & 20 \\
\hline GG & 2 & 2 & 0 & 40 \\
\hline
\end{tabular}

Source: Government Finance Statistics Yearbooks 2003-13.

Note: BCG is budgetary central government, CG is government, and GG is general government. See Note to Figure 3.

\section{B. Coverage of Stocks}

Second, there has also been an improvement in the reporting of fiscal stocks. In 2003, the mean score was 0.52 out of 3 ; by 2013, it was 0.82 . Figures 9 (a) and (b) show the changes in average scores by region and income group. As for other indicators of comprehensiveness, the countries that perform best include some advanced economies, but also some emerging and developing ones. Those that reported full balance sheets over most of the past decade include Australia, Hong Kong SAR, El Salvador, Japan, Norway, Russia, and the Slovak Republic.

Table 4 presents information on the transitions between the 2003 and 2013 Yearbooks. It shows, for example, that of the countries that reported only liabilities in 2003, 7 went on to produce a financial balance sheet and 4 a full balance sheet. Remarkably, 24 reported no balance-sheet subtotals in 2013. By contrast, no country that produced a financial or full balance sheet in 2003 went backwards. 
Figure 9. Average Comprehensiveness of the Coverage of Stocks, 2003-13

(a) By Region

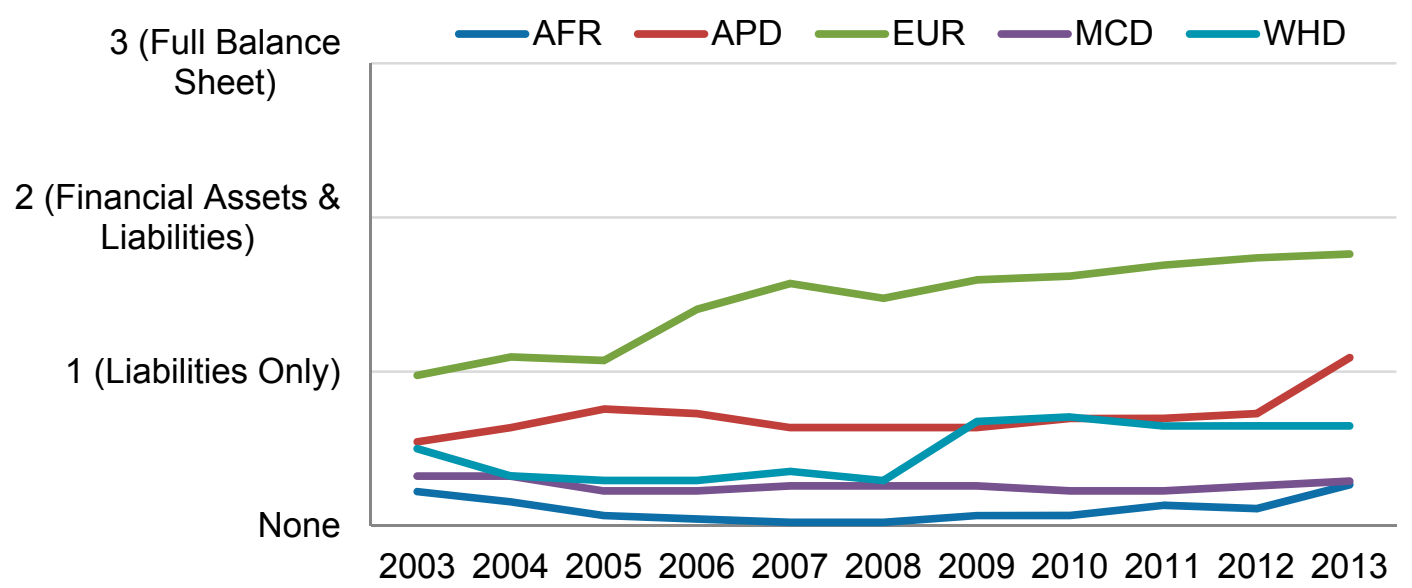

(b) By Income Group

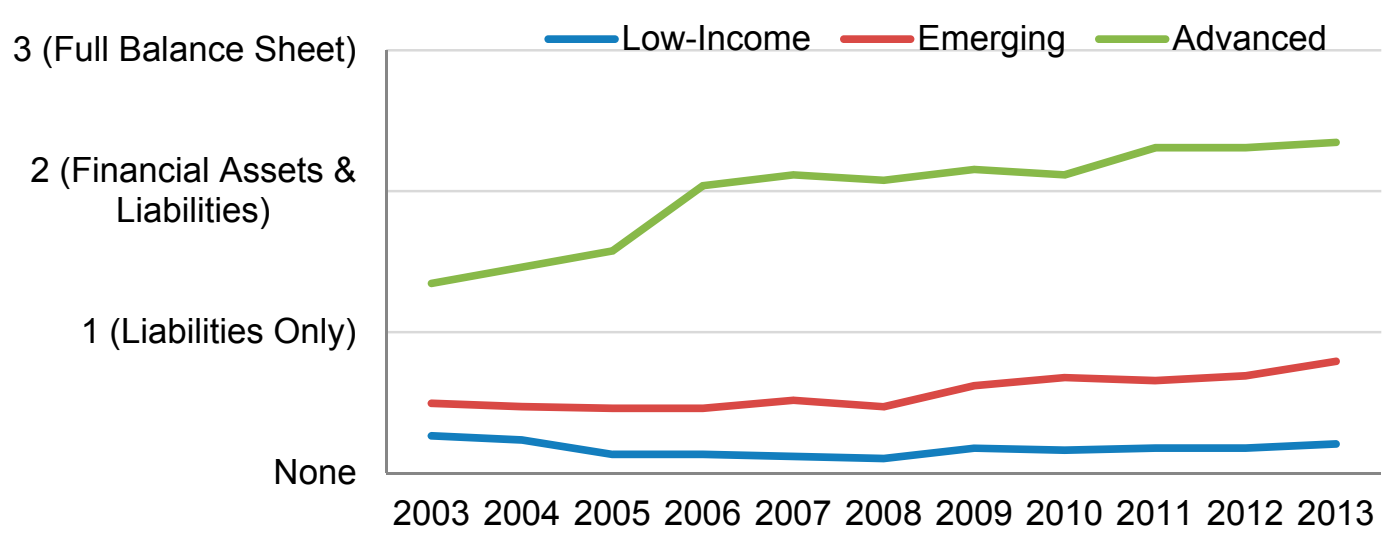

Source: Government Finance Statistics Yearbooks 2003-13.

Note: Almost all countries that report one subtotal report liabilities and almost all that report two report financial assets and liabilities. There are five exceptions. France reported only nonfinancial assets in 2003 and 2004, as did Jordan in 2011. Kazakhstan (2004) and Mongolia (2011) reported nonfinancial assets and liabilities, but not financial assets. See note to Figure 3. 
Table 3. Transitions in Coverage of Stocks, 2003-13

(a) Summary

\begin{tabular}{|c|c|c|}
\hline Color & Change & Number of Countries \\
\hline & Improved & 42 \\
\hline & Declined & 24 \\
\hline & No change & 120 \\
\hline
\end{tabular}

(b) Matrix

2013 GFS Yearbook

\begin{tabular}{|c|c|c|c|c|}
\hline & No Coverage & $\begin{array}{l}\text { Liabilities } \\
\text { Only }\end{array}$ & $\begin{array}{c}\text { Financial } \\
\text { Balance } \\
\text { Sheet }\end{array}$ & $\begin{array}{c}\text { Full } \\
\text { Balance } \\
\text { Sheet }\end{array}$ \\
\hline No Coverage & 87 & 9 & 7 & 14 \\
\hline $\begin{array}{l}\text { Liabilities } \\
\text { Only }\end{array}$ & 24 & 13 & 7 & 4 \\
\hline $\begin{array}{l}\text { Financial } \\
\text { Balance Sheet }\end{array}$ & 0 & 0 & 13 & 0 \\
\hline $\begin{array}{l}\text { Full Balance } \\
\text { Sheet }\end{array}$ & 0 & 0 & 0 & 7 \\
\hline
\end{tabular}

Source: Government Finance Statistics Yearbooks 2003-13.

Note: Years refers to Yearbooks, not year of data. See Appendix for details. We excluded France, which reported only nonfinancial assets in 2003 and a financial balance sheet in 2013. See Note to Figure 3.

\section{Coverage of Flows}

Lastly, there have been improvements in the comprehensiveness of the reporting of fiscal flows (Figure 10). In 2003, the mean score was 0.68 out of 3; by 2013, it was 0.97 . Most countries that report data report only a statement of the sources and uses of cash, but many members of the European Union report a statement of government operations but no other statement of fiscal flows. The fact that these European countries report only a single flow statement is one reason that the difference between Europe and other regions is smaller for the coverage of flows than for the other indicators. Only six economies reported all three statements in the 2013 Yearbook (Hong Kong SAR, Colombia, El Salvador, Lithuania, Russia, and Slovakia). Table 4 presents the transition matrix. 
Figure 10. Average Comprehensiveness of the Coverage of Flows, 2003-13 (a) By Region

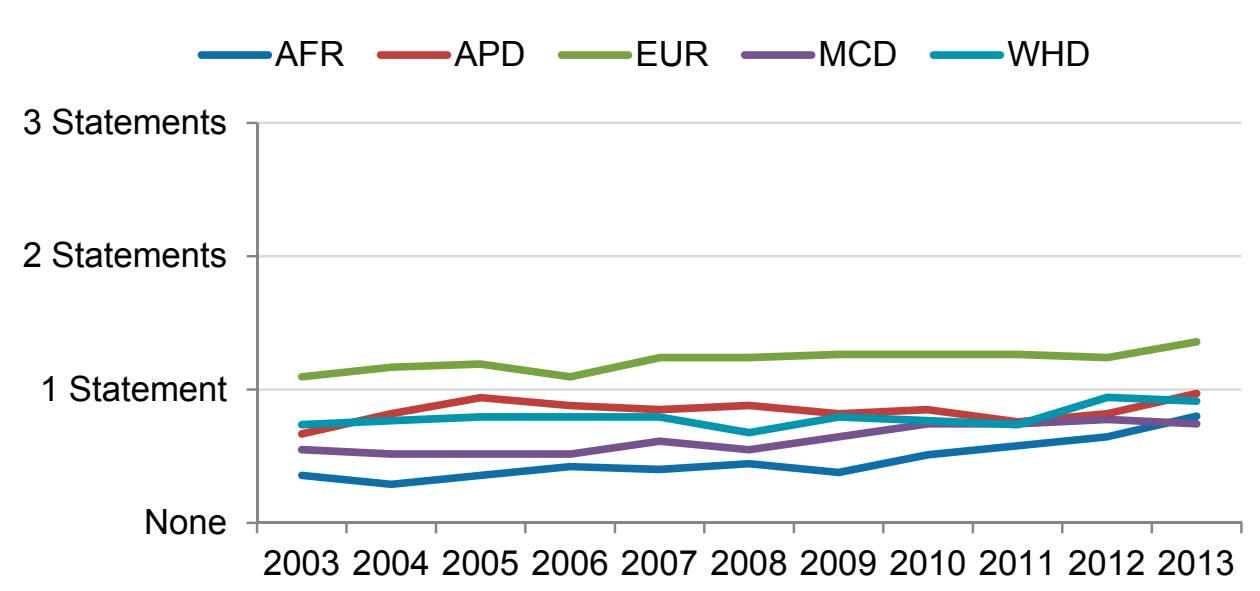

(b) By Income Group

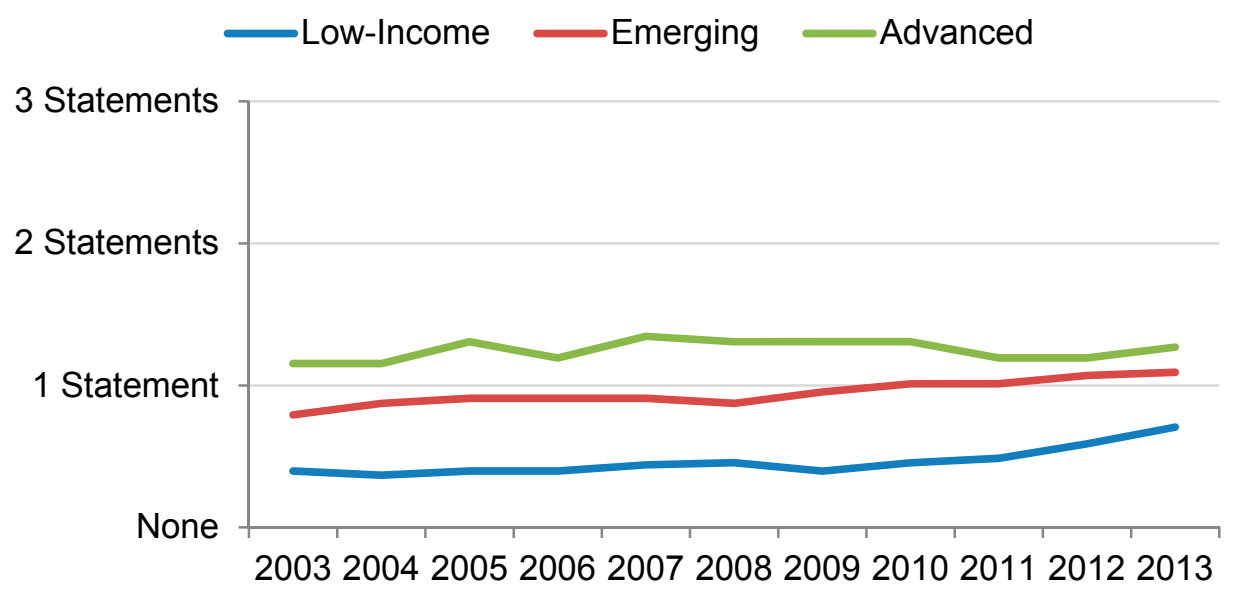

Source: Government Finance Statistics Yearbooks 2003-13.

Note: See Note to Figure 3. 
Table 4. Transitions in Coverage of Flows, 2003-13

(a) Summary

\begin{tabular}{|c|c|c|}
\hline Color & Definition & Number of Countries \\
\hline & Improved & 70 \\
\hline & Declined & 21 \\
\hline & No change & 95 \\
\hline
\end{tabular}

(b) Matrix

2013 GFS Yearbook

\begin{tabular}{|c|c|c|c|c|}
\hline & $\begin{array}{c}\text { No flow } \\
\text { statements }\end{array}$ & One & Two & Three \\
\hline $\begin{array}{l}\text { No flow } \\
\text { statements }\end{array}$ & 23 & 54 & 3 & 1 \\
\hline One & 12 & 65 & 10 & 2 \\
\hline Two & 1 & 5 & 4 & 0 \\
\hline Three & 0 & 2 & 1 & 3 \\
\hline
\end{tabular}

Source: Government Finance Statistics Yearbooks 2003-13.

Note: See Note to Figure 3.

\section{Conclusions}

The four GFS-based measures of the comprehensiveness of government finance statistics presented here show average improvements over the past decade, but the progress has been neither quick nor steady. Many countries moved forward, but some went backwards. Even in the most recent Yearbook, there are still only four countries-El Salvador, Hong Kong SAR, Russia, and the Slovak Republic - that report fully comprehensive government statistics, as we have defined them: a full balance sheet and a full set of flow statements for general government. Most advanced economies submit at least a financial balance sheet and one flow statement for general government, but in 2013 none submitted a full set of flow statementscash, accrual, and other economic flows - for any definition of government.

We hope the database presented here will be of use to researchers and others interested in tracking the progress of fiscal transparency, especially transparency about aggregate public finances. We also hope it will aid further research, including on the possible causes of fiscal 
transparency, such as democracy, reliance on tax revenues, and political competition. It may also be possible to investigate whether comprehensive fiscal statistics are facilitated by other factors, such as a tradition of central planning (consider Russia and the Slovak Republic) or an abundance of private-sector accountants familiar with balance sheets and both accrual and cash-based measures of financial flows. Finally, the new data may help cast light on the significance of fiscal transparency in improving fiscal outcomes. 


\section{Appendix 1. Calculating the Indices}

This appendix provides further details on the calculation of the indices outlined in Section II.

\section{Country coverage}

Only countries ${ }^{10}$ that joined the IMF in 2001 or earlier are included in the database. TimorLeste, Kosovo, Tuvalu, and South Sudan are therefore excluded. A few economies raise specific issues. First, the two Special Administrative Regions of China-Hong Kong and Macao - are counted separately from the People's Republic of China. This practice follows the approach of the GFS Yearbooks. Second, Serbia and Montenegro became separate countries in 2006. Before 2006, the two countries were one country known as "Serbia and Montenegro." After the split, the Republic of Serbia retained Serbia and Montenegro's membership, and the Republic of Montenegro joined the IMF. To account for this change, we count both the Republic of Serbia and the Republic of Montenegro (even though it was added to IMF membership after 2001) as separate countries for the whole period. To ensure consistency of number of countries before and after the split, any scores for Serbia and Montenegro before 2006 were counted twice - once each for the Republic of Serbia and the Republic of Montenegro. After 2006 the countries are scored independently.

Currently, there are 188 IMF member countries. Once the four post-2001 countries (excluding Montenegro for the reasons stated above) are excluded and Hong Kong and Macao are added, there are 186 countries and territories in the database.

\section{Timing conventions}

For some countries in some years GFS Yearbooks report very old data. In order to make sure that only relatively recent and therefore relevant data are assessed, only values from years $t-$ $3, t-2$, and $t-1$ are used to assess reporting in the Yearbook of year $t$. For example, for data collected from the 2005 Yearbook, only numbers reported for 2002, 2003, and 2004 are counted. Thus Belize is marked as "no assets or liabilities reported" for the 2004 Yearbook because the most recent data were for the year 1996. Preliminary or provisional numbers (denoted with a "p" in the Yearbooks) and any forecasted or projected numbers (denoted with an "f") are assessed in the same manner as actual numbers.

\footnotetext{
10"Country" "does not always refer to a territorial entity that is a state as understood by international law and practice; the term also covers the Euro area and some nonsovereign territorial entities, for which statistical data are provided internationally on a separate basis" (IMF GFS Yearbook 2012, p. v).
} 


\section{Calculating Index Scores: An Example}

To show how we record the data, we can take Austria as an example. Table A1 shows the four summary tables reported by Austria in the 2012 Yearbook. (Not included are several pages of more detailed information.) It is only these four summary tables that we examine. As the table shows, Austria reports a statement of government operations and a financial balance sheet, but no statement of other economic flows and no statement of the sources and uses of cash. As the table also shows, the Yearbook allows for only four sets of institutions. Here, they are central government, state government, local government, and general government. Thus, there is no room for data on budgetary central government or on extrabudgetary agencies.

\section{Table A1. Summary Statements for Austria, 2012 Yearbook}

\section{Austria $\quad 122$}

In Milions of Euros / Fiscal Year Ends December 31 / Data Reported through Eurostat

\begin{tabular}{|c|c|c|c|c|c|c|c|c|c|c|c|c|c|}
\hline & & \multicolumn{3}{|c|}{ Central Government } & \multicolumn{3}{|c|}{ State Government } & \multicolumn{3}{|c|}{ Local Government } & \multicolumn{3}{|c|}{ General Government } \\
\hline & & 2009 & 2010 & 2011 & 2009 & 2010 & 2011 & 2009 & 2010 & 2011 & 2009 & 2010 & 2011 \\
\hline \multicolumn{2}{|c|}{ Statement of government operations } & & & & & & & & & & & & \\
\hline 1 & Revenue. & 101,033 & 104,711 & 109,137 & 25,437 & 25,655 & 27,106 & 21,770 & 22,135 & 23,189 & 133,942 & 137,765 & 144,449 \\
\hline 2 & Expense. & 109,759 & 114,090 & 115,914 & 27,452 & 27,962 & 27,963 & 22,691 & 23,816 & 23,927 & 145,604 & 151,132 & 152,820 \\
\hline GOB & Gross operating balance.................. & $-7,694$ & $-8,318$ & $-5,693$ & $-1,109$ & $-1,364$ & 108 & 686 & -29 & 933 & $-8,117$ & $-9,712$ & $-4,652$ \\
\hline NOB & Net operating balance.................... & $-8,726$ & $-9,379$ & $-6,777$ & $-2,015$ & $-2,307$ & -856 & -921 & $-1,681$ & -738 & $-11,662$ & $-13,367$ & $-8,371$ \\
\hline 31 & Net acquisition of nonfinancial assets.... & -100 & -49 & -68 & -36 & -39 & -137 & -136 & -451 & -621 & -271 & -539 & -826 \\
\hline NLB & Net lendinglborrowing ..................... & $-8,626$ & $-9,330$ & $-6,709$ & $-1,980$ & $-2,268$ & -719 & -786 & $-1,230$ & -117 & $-11,391$ & $-12,828$ & $-7,545$ \\
\hline 32 & Net acquisition of financial assets...... & 1,097 & 778 & 2,740 & 247 & 467 & 887 & 643 & 329 & 772 & $-1,772$ & 1,624 & 4,850 \\
\hline 33 & Net incurrence of liabilities. & 10,210 & 10,460 & 9,797 & 2,797 & 3,245 & 872 & 1,521 & 1,671 & 1,102 & 10,769 & 15,425 & 12,221 \\
\hline NLB & 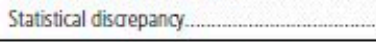 & -487 & -352 & -348 & -570 & -510 & 734 & -92 & -111 & -213 & $-1,150$ & -973 & 174 \\
\hline \multicolumn{14}{|c|}{ Statement of other economic flows } \\
\hline \multicolumn{2}{|c|}{ Balance sheet } & & & & & & & & & & & & \\
\hline 6 & Net worth.................. & $\cdots$ & $\cdots \cdot$ & $\cdots$ & $\cdots$ & .... & $\cdots \cdot$ & $\cdots$ & & $\cdots$ & $\cdots$ & $\cdots$ & .... \\
\hline 61 & Nonfinancial assets... & $\ldots$ & $\ldots$ & $\ldots$ & $\ldots$ & $\ldots$ & $\ldots$ & $\ldots$ & $\ldots$ & $\ldots$ & $\ldots$ & $\ldots$ & .... \\
\hline 62 & Financial assets.......... & 58,618 & 63,177 & 64,919 & 28,667 & 28,946 & 29,863 & 19,645 & 20,051 & 20,727 & 92,817 & 97,608 & 101,611 \\
\hline & Liabilities....................... & 197,175 & 212,047 & 225,452 & 14,118 & 17,579 & 18,507 & 7,080 & 8,874 & 10,011 & 204,259 & 223,934 & 240,071 \\
\hline State & ement of sources and uses of cash & & & & & & & & & & & & \\
\hline
\end{tabular}

Source: International Monetary Fund, Government Finance Statistics Yearbook, 2012, p. 77

\section{The Database}

Reporting is recorded for the intersection of each sector and each financial statement in the following way:

- A " 1 " means that data were reported for this particular sector and statement.

- A " 0 " means that space was provided this particular sector and statement, but no data were reported.

- An " $\mathrm{x}$ " means that this particular combination of sector and statement is not applicable to the country.

- A blank cell means that the country was not included in the GFS Yearbook. One possible reason for this is that the country did not report any data to the GFS system in that particular year. 
Table A2 shows the information gathered from Table 1. It indicates that Austria reports the statement of government operations and the financial balance sheet for (among other sets of institutions) central government and general government.

Table A2. Basic Data for Austria, 2012 Yearbook

\begin{tabular}{|c|c|c|c|c|c|c|}
\hline Level of Government & $\begin{array}{c}\text { Budgetary } \\
\text { Central }\end{array}$ & Central & General & Local & State & $\begin{array}{c}\text { Extra- } \\
\text { budgetary } \\
\text { Funds }\end{array}$ \\
\hline $\begin{array}{l}\text { Statement of } \\
\text { Government } \\
\text { Operations }\end{array}$ & $\mathrm{x}$ & 1 & 1 & 1 & 1 & $\mathrm{X}$ \\
\hline $\begin{array}{l}\text { Statement of Other } \\
\text { Economic Flows }\end{array}$ & $\mathrm{x}$ & 0 & 0 & 0 & 0 & $\mathrm{X}$ \\
\hline \multicolumn{7}{|l|}{ Balance Sheet } \\
\hline Liabilities & $\mathrm{x}$ & 1 & 1 & 1 & 1 & $\mathrm{X}$ \\
\hline Financial Assets & $\mathrm{x}$ & 1 & 1 & 1 & 1 & $\mathrm{X}$ \\
\hline Nonfinancial Assets & $\mathrm{x}$ & 0 & 0 & 0 & 0 & $\mathrm{X}$ \\
\hline $\begin{array}{l}\text { Statement of Sources } \\
\text { and Uses of Cash }\end{array}$ & $\mathrm{X}$ & 0 & 0 & 0 & 0 & $\mathrm{X}$ \\
\hline
\end{tabular}

\section{Overall GFS-based index}

Austria reports three items for general government, each of which generates a score of 3 . The three items are the statement of government operations plus the two subtotals of the summary balance sheet (liabilities and financial assets). The other items receive a score of 0 because they were not reported for any of the main definition of government (general government, central government, and budgetary central government). The final overall score is the sum of all six scores (three $3 \mathrm{~s}$ and three $0 \mathrm{~s}$ ), giving Austria a score of 9 out of 18, which we scale up to 50 out of 100 . 


\section{Coverage of stocks}

As noted in the text, the coverage of fiscal stocks is determined by evaluating the reporting of subtotals for liabilities, financial assets, and nonfinancial assets in the summary balance sheet. These subtotals are coded as numbers 61, 62, and 63, respectively. A full balance sheet consists of all three subtotals. A partial balance sheet consists of two of the three subtotals, most often liabilities and financial assets. The exceptions are Kazakhstan and Mongolia, which reported nonfinancial assets and liabilities in the 2004 and 2011 Yearbooks, respectively. An even less complete balance sheet consists only of one subtotal, which is almost always for liabilities. The exceptions are France and Jordan, which reported nonfinancial assets only in the 2003 and 2004 Yearbooks (France), and the 2005 Yearbook (Jordan). Table A3 illustrates the information gathered on coverage of stocks for Austria in 2012.

Table A3. Coverage of Stocks, Austria, 2012 Yearbook

\section{Budgetary Central Central}

General

Balance Sheet

Liabilities

Financial Asset

Nonfinancial Assets

\begin{tabular}{lll}
$\mathrm{X}$ & 1 & 1 \\
$\mathrm{X}$ & 1 & 1 \\
$\mathrm{X}$ & 0 & 0 \\
\hline
\end{tabular}

An overall rating is calculated from the number of subtotals reported as follows:

- A " 0 " is given if nothing is reported.

- A " 1 " is given if one of the balance-sheet subtotals is reported.

- A " 2 " is given if two of the balance-sheet subtotals are reported.

- A " 3 " is given if all three subtotals are reported.

In considering balance-sheet reporting, we make only very weak demands on the institutional coverage. We count a country as reporting liabilities if it reports them for at least one of budgetary central government, central government, and general government. If a country reports balance sheets only for local government, state government, or extrabudgetary funds sectors, we did not consider it to report a balance sheet. 
Given the information in Table A3, Austria gets a score of 2 for coverage of fiscal stocks.

Coverage of flows

The existence of the other three statements-government operations, other economic flows, and sources and uses of cash - is taken to indicate the comprehensiveness of a country's coverage of fiscal flows. Table A4 illustrates the information gathered on coverage of flows for Austria from the 2012 Yearbook.

Table A4. Coverage of Flows in Austria, 2012 Yearbook

\begin{tabular}{|lccc|}
\hline \multicolumn{1}{|c}{ Level of Government } & $\begin{array}{c}\text { Budgetary } \\
\text { Central }\end{array}$ & Central & General \\
\hline Statement of Government Operations & $\mathrm{x}$ & 1 & 1 \\
\hline Statement of Other Economic Flows & $\mathrm{x}$ & 0 & 0 \\
\hline Statement of Sources and Uses of Cash & $\mathrm{x}$ & 0 & 0 \\
\hline
\end{tabular}

An overall rating is calculated from the number of statements reported:

- A " 0 " is given if none of these statements is reported.

- $\quad \mathrm{A}$ " 1 " is given if one of the statements is reported

- $\quad$ A " 2 " is given if two statements are reported.

- A " 3 " is given if all three statements are reported.

In considering the reporting of fiscal flows, we are again relatively undemanding about the institutional coverage of the statements. Statements for budgetary central government, central government, and general government are counted.

Given the data in Table A4, Austria gets a score of 1 for coverage of fiscal flows.

\section{Coverage of institutions}

The comprehensiveness of the coverage of fiscal institutions is indicated by the broadest sector that it reports information for, among budgetary central government, central government, and general government. Table A5 illustrates the information gathered on coverage of institutions for Austria from the 2012 Yearbook. 
Table A5. Coverage of Institutions in Austria, 2012 Yearbook

\begin{tabular}{|lccc|}
\hline \multicolumn{1}{|c|}{ Level of Government } & $\begin{array}{c}\text { Budgetary } \\
\text { Central }\end{array}$ & Central & General \\
\hline $\begin{array}{l}\text { Statement of Government } \\
\text { Operations }\end{array}$ & $\mathrm{x}$ & 1 & 1 \\
\hline $\begin{array}{l}\text { Statement of Sources and Uses } \\
\text { of Cash }\end{array}$ & $\mathrm{x}$ & 0 & 0 \\
\hline
\end{tabular}

An overall rating is calculated from the governments sectors reported:

- A " 0 " is given if there is no information reported.

- A " 1 " is given if there is information for the budgetary central government but not central government or general government.

- A " 2 " is given if there is information for the central government but not general government.

- A " 3 " is given if there is information for the general government.

In considering the coverage of institutions, we are not strict about the financial statements that are reported. For example, a country is counted as reporting for general government data if it reports for that coverage either the statement of government operations or the statement of sources and uses of cash.

Given the data in Table A5, Austria gets a score of 3 for coverage of institutions.

\section{Alternatives}

The indicators of the comprehensiveness of GFS could of course be calculated differently. The overall index, for example, could be calculated by summing the three indicators for institutions, stocks, and flows. We have preferred a multiplicative approach because this gives countries credit for reporting comprehensive measures of stock and flows for a comprehensive definition of government. Simply adding the components would give these countries no more credit than that received by countries reporting comprehensive measures of stocks and flows for a narrow definition of government and narrow measures of stocks and flows for a broad definition of government. Further, instead of simply counting the number of reported balance-sheet subtotals and flow statements, we could have ordered them and given higher scores to countries reporting items that were considered "more advanced."

- The reporting of accrual flows is often considered more useful than the reporting of cash flows. Moreover, countries that report accrual flows might be considered capable of reporting cash flows and might in fact report them elsewhere, even if they do not report them to the IMF for inclusion in GFS Yearbooks. On these grounds, 
countries reporting a cash-flow statement but not an accrual-based statement of government operations might be given a score of 1 and countries reporting a statement of government operations a score of 2 whether or not they reported a cashflow statement. We have not done this, because we prefer to avoid controversial judgments and to assume only that is better to report both accrual flows and cash flows than to report only one of these. ${ }^{11}$

- In the case of stocks, we could likewise have given a 1 to countries reporting liabilities (the most common balance-sheet subtotal), a 2 to countries reporting financial assets (irrespective of whether they reported liabilities), and a 3 to countries reporting nonfinancial assets (irrespective of what else they reported). We have not done so, but in this case it would have made almost no difference, since with very few exceptions countries report liabilities before assets and financial assets before nonfinancial assets.

- For institutions, we do choose an approach that ranks the alternatives, rather than simply counting the sets of institutions for which the information is supplied. As noted above, we exclude extrabudgetary institutions, local government, and state government, because not all countries have them, which leaves budgetary central government, central government, and general government. We rank these partly because there is little or no reason for having information on budgetary central government if there is information on central government (the category may exist mainly because many governments are not capable of producing information on central government), and partly because we assume that the governments that produce information on general government will generally publish information on central government.

We stress, however, that researchers do not need to accept our choices and can use the database to construct alternative indices as they see fit.

\footnotetext{
${ }^{11}$ Similarly, we could have given a score of 3 to countries reporting other economic flows on the grounds that their reporting was probably sufficiently advanced that they were also capable of producing a statement of government operations and a cash-flow statement.
} 


\section{Appendix 2. Deriving an Indicator of Fiscal Transparency from PEFA Reports}

This appendix explains the construction of the PEFA-based indicator of transparency discussed in Section III.

One hundred and fifty three Public Expenditure and Financial Accountability (PEFA) reports have been done for 91 mainly developing or emerging economies, some of them selfassessments. Each report includes a systematic assessment of public financial management based on the PEFA framework (for details, see PEFA, 2011). There is a single report for 42 countries, two reports for 37 countries, three reports for 11 countries, and four reports for 1 country.

In the existing PEFA framework (the framework is in the process of being updated) PI-10 is the only indicator that explicitly measures the public availability of fiscal information. It has four relevant components ((i)-(iv)), which indicate the availability of, respectively, the budget, in-year budget-execution reports, year-end financial statements, and an audit report.

Other indicators combined with PI-10, however, provide additional information. PI-1 (Aggregate expenditure out-turn compared to original approved budget), PI-5 (Classification of the budget), and PI-6 (Comprehensiveness of information included in budget documentation) all measure the quality and comprehensiveness of budget documentation. When paired with PI-10(i), these provide a view of the quality of publicly available budget documentation. Similarly, PI-24 (Quality and timeliness of in-year budget reports) can be paired with PI-10(ii) to provide a similar assessment of in-year budget reports. PI-25 (Quality and timeliness of annual financial statements) can be paired with PI-10(iii) for year-end financial statements. And PI-26 (Scope, nature, and follow-up of external audit) can be paired with PI-10(iv) for external audit reports.

More specifically, we assess the quality of publicly available fiscal information of various types by multiplying two scores. The components of PI-10 (i, ii, iii, iv) are given a value of 1 or 0 depending on whether the documentation is publicly available or not. The value for PI10(i) is then multiplied by the average of the scores for PI-1, PI-5, and PI-6. The values for PI-10(ii, iii, and iv) are multiplied, respectively, by the scores for PI-24, PI-25, and PI-26. The scores for each indicator are based on letter grades in the PEFA reports, which we convert into numbers. A score of " $\mathrm{A}$ " is converted to a 4.0 , a " $\mathrm{B}+$ " is 3.5 , a " $\mathrm{B}$ " is 3.0 , a " $\mathrm{C}+$ " is a 2.5 , and so on. The lowest non-zero score is a " $\mathrm{D}$ ", which is a 1.0. All "NA", "NR", or "NU" scores are given a 0 .

Figure A1 shows that South Africa scores highest on our PEFA-based index of fiscal transparency. Other emerging markets, such as Peru, Serbia, Colombia, Indonesia, and Brazil also do well. Table A6 shows descriptive statistics for the PEFA-based index. 
Figure A1. Top PEFA Scorers

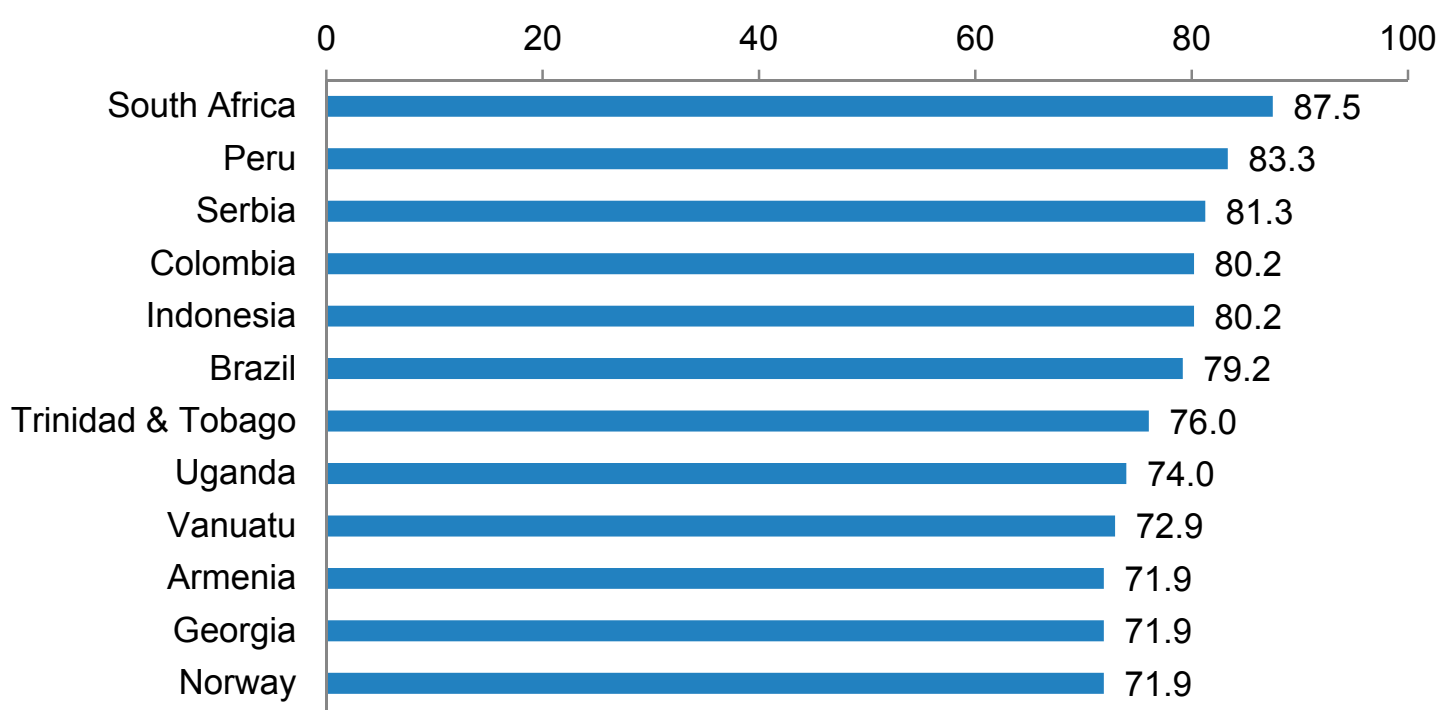

Note: Maximum Score is 16.

Table A6. Descriptive Statistics for PEFA Indicators

\begin{tabular}{lcccc}
\hline & Mean & Median & Maximum & Minimum \\
\hline $\begin{array}{l}\text { Total Score } \\
\text { (Out of 100) }\end{array}$ & 34.7 & 34.4 & 87.5 & 0.0 \\
$\begin{array}{l}\text { Annual Budget } \\
\begin{array}{l}\text { Out of 4) } \\
\text { In-Year Execution Reports }\end{array}\end{array}$ & 1.9 & 2.3 & 4.0 & 0.0 \\
$\begin{array}{l}\text { (Out of 4) } \\
\begin{array}{l}\text { Year-End Financial } \\
\text { Statements }\end{array}\end{array}$ & 1.4 & 1.5 & 4.0 & 0.0 \\
$\begin{array}{l}\text { (Out of 4) } \\
\text { External Audit Reports }\end{array}$ & 1.2 & 0.0 & 4.0 & 0.0 \\
(Out of 4) & 1.3 & 1.5 & 3.5 & 0.0 \\
\hline
\end{tabular}




\section{References}

Alt, James E., and David Dreyer Lassen, 2006, "Fiscal Transparency, Political Parties, and Debt in OECD Countries," European Economic Review Vol. 50, pp. 403-1439.

Alt, James E., David Dreyer Lassen, and Shanna Rose, 2006, "The Causes of Fiscal Transparency: Evidence from the US States, Staff Papers, International Monetary Fund, Vol. 53 (special issue), pp. 30-57.

Alt, James, David Dreyer Lassen, and Joachim Wehner, 2014, “It Isn't Just about Greece: Domestic Politics, Transparency, and Fiscal Gimmickry in Europe," British Journal of Political Science.

Bernoth, Kerstin, and Guntram B. Wolff, 2006, Fool the Markets? Creative Accounting, Fiscal Transparency and Sovereign Risk Premia, Deutsche Bundesbank, Discussion Paper Series 1: Economic Studies No 19/2006.

Blondy, Guilhem, July Cooper, Timothy Irwin, Kris Kaufmann, and Abdul Khan (2013) "The Role of Fiscal Reporting in Public Financial Management." Chap. 8 in Marco Cangiano, Teresa Curristine, and Michel Lazare (eds.), Public Financial Management and its Emerging Architecture (Washington: International Monetary Fund).

Dabla-Norris, Era, Richard Allen, Luis-Felipe Zanna, Tej Prakash, Eter Kvintradze, Victor Lledo, Irene Yackovlev, and Sophia Gollwitzer, 2010, Budget Institutions and Fiscal Performance in Low-Income Countries, IMF Working Paper WP 10/80 (Washington: International Monetary Fund).

de Renzio, Paolo, and Joachim Wehner, 2015, The Impacts of Fiscal Openness: A Review of the Evidence.

Economist Intelligence Unit, 2012, Democracy at a Standstill, Democracy Index 2012.

Eurostat, 2013, Manual on Government Deficit and Debt, Methodologies and Working Papers (Luxembourg: European Union).

Global Initiative for Fiscal Transparency (GIFT), 2012, High-Level Principles on Fiscal Transparency, Participation, and Accountability, August 4.

Hughes, Richard, Tom Josephs, Viera Karolova, Vladimir Krivenkov, and Gösta Ljungman, 2014, Russian Federation: Fiscal Transparency Evaluation, (Washington: International Monetary Fund).

Hameed, Farhan, 2005, Fiscal Transparency and Economic Outcomes, IMF Working Paper WP 05/2225 (Washington: International Monetary Fund). 
International Budget Partnership, (IBP), 2011, Open Budget Questionnaire, June 2011. , 2013, Open Budget Survey 2012.

International Monetary Fund, 1986, A Manual on Government Finance Statistics (Washington). , 2001, Government Finance Statistics Manual, 2001 (Washington). , 2007, Manual on Fiscal Transparency (Washington). ,2012, Fiscal Transparency, Accountability, and Risk (Washington). , 2014, Fiscal Transparency Code (Washington). , 2015, Government Finance Statistics Manual, 2014 (Washington). , all years in 2003-2014, Government Finance Statistics Yearbook (Washington).

Irwin, Timothy C., 2013, "Shining a Light on the Mysteries of State: The Origins of Fiscal Transparency in Western Europe," IMF Working Paper WP 13/219 (Washington: International Monetary Fund).

International Public Sector Accounting Standards Board (IPSASB), 2014, Handbook of International Public Sector Accounting Pronouncements.

Jarmuzek, Mariusz, Eva Katalin Polgar, Roman Matousek, and Jens Hölscher, 2006, Fiscal Transparency in Transition Economies, Case Center for Social and Economic Research Paper 328.

Khagram, S., Paolo de Renzio, and Archon Fung, 2013, "Overview and Synthesis: The Political Economy of Fiscal Transparency, Participation, and Accountability around the World," Chap 1 of Khagram, de Renzio, and Fung (eds.) Open Budgets: The Political Economy of Transparency, Participation, and Accountability (Brookings).

Koen, V., and P. van den Noord, 2005, Fiscal Gimmickry in Europe: One-Off Measures and Creative Accounting, OECD Economics Department Working Papers 417 (Paris: Organization for Economic Cooperation and Development).

Organization for Economic Cooperation and Development (OECD), 2002, Best Practices for Budget Transparency (Paris).

Public Expenditure and Financial Accountability (PEFA) Secretariat, 2011, Public Financial Management Performance Measurement Framework Revised January 2011 (Washington: PEFA Secretariat). 
Seiferling, Mike, 2012, Stock-Flow Adjustments, Government's Integrated Balance Sheet, and Fiscal Transparency, IMF Working Paper WP 13/63 (Washington: International Monetary Fund).

Seiferling, Mike, and Shamsuddin Tareq, 2015, Fiscal Transparency and the Performance of Government Financial Assets, IMF Working Paper WP 15/9 (Washington: International Monetary Fund).

Weber, Anke, 2012, Stock-Flow Adjustments and Fiscal Transparency: A Cross-Country Comparison, IMF Working Paper WP 12/39 (Washington: International Monetary Fund).

Wehner, Joachim, 2006, “Assessing the Power of the Purse: An Index of Legislative Budget Institutions," Political Studies Vol. 54, pp. 767-785. 